\title{
Türkiye’de Köy Sosyolojisi Araştırmaları ile Köy Enstitüleri Fikrinin İlişkisel Incelenmesi
}

\author{
Relational Examination of Rural Sociology Research and the İdea of Village Institutes in Turkey \\ İlyas Sucu ${ }^{\text {a,* }}$ \\ ${ }^{a}$ Dr. Öğr. Üyesi, Ondokuz Mayıs Üniversitesi, Fen Edebiyat Fakültesi, Sosyoloji Bölümü, 55139, Samsun/Türkiye. \\ ORCID: 0000-0003-0506-5690
}

\section{MAKALE BILGISİ \\ Makale Geçmişi: \\ Başvuru tarihi: 30 Eylül 2020 \\ Düzeltme tarihi: 17 Ekim 2020 \\ Kabul tarihi: 28 Ekim 2020}

\section{Anahtar Kelimeler:}

Köy Enstitüleri

Köy sosyolojisi

Toplumsal değişme

\section{ARTICLE INFO}

Article history:

Received 30 September 2020

Received in revised form 17 October 2020

Accepted 28 Ekim 2020

\section{Keywords:}

Village Institutes

Rural sociology

Social change
ÖZ

Köy Enstitüleri'nin kuruluş tartışmalarından kapatılmasına kadar devam eden süreçte Türk sosyolojinde yapılan üç farklı köy araştırma türü vardır. Bunlar Sosyal Bilim Ekolü'nün monografik köy araştırmaları (1936-1952); Mümtaz Turhan'ın köy araştırması (1936-1948) ile Niyazi Berkes ve Behice Boran'ın köy araştırmalarıdır (1939-1942). İlki, bireyci bir toplum yapısını hedefleyen ve bu amaçla kişisel girişkenliği esas alan bir toplumsal değişim önermektedir. İkincisi, toplumsal değişmede zihniyet unsurlarını öne çıkarmakta ve sentezci bir anlayışla köye ve köylü eğitimine yaklaşmaktadır. Üçüncüsü ise köyde altyapısal/teknolojik bir değişimi öncelemekte ve bu sürecin doğal sonucu olarak toplumsal değişimi öngörmektedir. Bu çalışmada enstitülerin hedeflediği toplumsal değişimle sosyolojideki köy araştırmalarının sonuçları arasındaki ilişki incelenmiştir. Sosyo-kültürel kurum inşasında toplumsal yapı araştırmaların önemi, Köy Enstitüleri deneyimiyle açığa çıkarılmıştır.

\section{Giriş: Cumhuriyet Döneminde Köye Yönelik İlginin Kaynakları}

Osmanlı İmparatorluğu'nun yıkılışı ve Cumhuriyet'in ilanıyla birlikte ülkemizde, köy ve köycülük önemli bir ilgi alanı olarak karşımıza çıkmaktadır. Bu ilginin başlangıcı II. Meşrutiyet'in ilanı sonrası dönem olmakla birlikte bu dönemdeki ilgi oldukça sınırlı düzeyde kalmıştır. Aslında 1858'de Arazi Капиnu yürürlüğe girmiş ve kanunla birlikte devletin köylüyle ve toprakla olan mevcut ilişki biçimi tümüyle tadil edilmişti. Fakat bu oldukça önemli değişiklik, devletin batılılaşma tercihine ve biçimine koşut olarak köyden/köylüden başlayan bir değişism talebinin sonucu değildir. Bizzat yönetici kadroların kararıyla biçimlenen bir düzenlemedir. Bu düzenleme ancak batılılaşmanın "devleti yıkılmaktan kurtarmak ve kalkındırmak" adına zorunlu bir tercih olarak ortaya koyulduğu siyasal tercih sürecinde anlam kazanabilir. Devlet düzeyinde köye ve toprak sistemine dair bu ilgi ve düzenlemeler, düşünsel alanda sınırlı bir ilgi uyandırmıştır. Tanzimat ve Meşrutiyet dönemlerinde bazı değiniler ${ }^{1}$ ile edebiyattaki bazı örnekler

\footnotetext{
${ }^{1}$ II. Meşrutiyet döneminde yayınlanan Yeni Mektep mecmuası, maarifle ilgili çeşitli kurumlarda idarecilik yapmış Ethem Nejat'ın ilgisi (Kafadar, 2012: 369) ve Ahmet Rıza'nın gençliğinde kendisini derin düşüncelere sevk ettiğini söylediği Anadolu köyleri (Mardin, 2008: 178), bu değinilerden bazılarıdır.
} 
dışında meselenin gerek fikri düzlemde ele alınıp tartışıldığı gerekse de köylünün toplumsal bir değişim talebinin aktörü olduğu bir ortam söz konusu değildir.

Ertürk'ün bildirdiği üzere (1997: 25) Batı'da başlayan köy tartışmalarına ilgi göstermemiş olmamıza, Batı'dan yapılan köy temalı aktarmaların da yankı uyandırmamış olmasına karşılık, Batılıların Türk köyüne, onun kimi yanlarına dikkat çektikleri bilinmektedir. Fakat bu çabaların Osmanlı düşün dünyasında çok az yazar tarafindan ilgi görmesi, köye ilginin Osmanlı'da yaygınlaştırılmak istenmesine karşılık etkili olamadığını bize göstermektedir. Buna rağmen devlet, geleneksel siyasetini terk edip Batıcı seçimi yaptığında ilk köklü düzenlemeyi köyle ilişkisinde gerçekleştirmiş, yeni girdiği ilişkilerden geri dönmeyi önlemek, toplumla eski bağlarını ve ilişkilerini tasfiye etmek için, Batı ile ilişkiden elde edeceği imkânlara karşılık köyle ilişkisini kökten değiştirmiştir.

Köye dönük ilgi ve köye yönelme, ya da diğer bir deyişle devletin Batılaşma seçiminin bir sonucu olarak köyle ilişkinin kökten değişimi, Cumhuriyet'in ilanı sonrası belirgin bir siyasete dönüşmüştür. $\mathrm{Bu}$ dönemde de Cumhuriyet öncesi dönemde olduğu gibi köye ilginin kökeninde köy ve köylüden kaynaklı, yani köylünün talepleri üzerine kurulu bir siyasetten ziyade devletin politik tercihi söz konusu olmuştur. Köy Kanunu ve Köy Ĕgitimi Yasası'nın çıkarılması ile Aşar Vergisi'nin kaldırılması gibi yasal düzenlemeler; örnek çiftlik uygulamalarının başlaması, Ziraat Bankası'nın kurulması, şeker fabrikalarının açılması gibi tarımda iktisadi kalkınma hamleleri; köy eğitmen kursları, ziraat mektepleri ile köy ilkokullarının açılması gibi eğitsel/kültürel politikalar, tam da Cumhuriyet'in hemen ertesinde 1924 itibariyle başlatılan ve 1930'a kadarki köy politikalarına örnektir. Cumhuriyet sonrası köye dönük ilginin edebi/düşünsel alandaki izleri ise büyük oranda 1930 sonrasında izlenebilmektedir. ${ }^{2}$

Köye yönelik bu ilgi iki temel gerekçe üzerinden açıklanabilir. İlki köyün yeni kurulan devletin varlığını sürdürebilmesinin kaynağ tek refah üretici kaynağı olmasıdır. Şöyle ki, 1927 nüfus verilerine göre ülke nüfusu 13,7 milyondur. $\mathrm{Bu}$ nüfusun \%75,8'i ise köylerde ikamet etmektedir. Nüfusun köy-kent dağılım oranı, 1950 yılına kadar bu şekilde devam etmiştir. 1950 nüfus sayımında ülke nüfusu 18,8 milyon olarak tespit edilmişken bu nüfusun \%75'inin hâlâ köylü nüfusu olduğu gerçeği karşımıza çıkmaktadır (Tekeli \& Gülöksüz, 1985: 1232). ${ }^{3}$ Ülke nüfusunun dörtte üçünün köylü nüfusu olmasının yanı sıra bir diğer husus da ülke ekonomik göstergelerindeki tarım ağırlığıdır. 1935 verilerine göre faal nüfusta tarımsal nüfusun oranı \%80, 1925-1944 y1lları arasında gayri safi yurtiçi hâsılada tarımsal gelirin oranı $\% 46,5$ ve $1925-1940$ yılları arasinda ihracatta tarım ürünlerinin pay1 \%87'dir (Kazgan, 1985: 2413). İstihdam oranları da bu şekildedir. Mesela 1923'de tarımdaki istihdam, tüm istihdamın \%90'ını oluşturmaktadır. Bu oran 1950'de ancak \%84'e gerileyebilmiştir (Yıldırım, 2019: 224). Köylü ve zirai sektörün bu şekilde yeni devletin temel zenginlik kaynağı olduğunun mottosu ise "köylü milletin

\footnotetext{
${ }^{2}$ Köye dönük ilginin edebi/düşünsel alandaki izlerini görmek için bkz. Ertürk, 1997.

${ }^{3}$ Köy-kent nüfus oranın 1927'den 1950'ye değin neredeyse aynı oranda seyretmiş olması, modernleşmenin tek parti dönemindeki biçimini anlamak açısından dikkat çekicidir.
}

efendisidir" sözüdür. ${ }^{4}$ Atatürk'e ait olan bu sözün formülasyonunu ise Şükrü Kaya yapmıştır: "Köy, nüfusumuzun \%70'ini içinde yaşatan en tabii ve en esaslı müessese; köy, bütün gıda ve hammaddelerin kaynağı; köy, en büyük ihracatçı; köy, en büyük ve sağlam müşteri; köy, ordumuzun temeli; köy, kısaca Türkiye'dir" (Ertürk, 1997: 70). Köyün zenginliği toplumun zenginliği olarak tanımlanmıştır. Köyün zenginlik kaynağı olarak görülmesiyle birlikte bir "köycülük davası"nın başladığı görülmektedir.

$\mathrm{Bu}$ noktanın devamında köye ilginin ikinci gerekçesine geçilebilir. Cumhuriyet sonrası -özellikle de 1930 sonrasıköye yönelik ilginin ikinci gerekçesi ideolojiktir. Bilindiği üzere gerek Meşrutiyet gerekse Cumhuriyet döneminin kurucu ideologu Ziya Gökalp, Meşrutiyet döneminde kaleme aldığ 1 ve 1924 'e kadar israrla vurguladığ Türkleşmek, Iślamlaşmak, Muasırlaşmak sentezi çerçevesinde Osmanli/Türk modernleşmesini ele almaktaydı. Fakat Halifeliğin ilgası ve birlikte yapılan bazı dini düzenlemelerle birlikte Gökalpçı sentez hem İslamcılığı sentezden düşürmüş hem de yeni rejimi öne çekerken Osmanlılığı geriye itmiştir. Gökalp'ın ulusal bilinci oluşturma çabasında Orta Asya Türklerine kadar giderken, Osmanlı bakiyesi üzerine kurulu Türkiye Cumhuriyeti'nden Osmanlı'yı olabildiğince uzaklaştırması bu sebepledir. ${ }^{5}$ İslamcılığın sistemden nakıs bırakılması ve devletin kurtarılması sonrasinda toplumun bir erek etrafinda birleşmesini sağlayacak temel öğe arayışı, milliyetçilik ${ }^{6}$ fikrinin öne çıkarılmasına yol açmıştır.

Cumhuriyet dönemi köy tartışmaları bir yandan köy/toplum kalkınmasıyla ilgiliyse de diğer taraftan da yeni rejimin meşruiyet sorunlarıyla alakalıdır. Türkiye Cumhuriyeti, Tanzimat'la başlayan Osmanlı modernleşmesinde en önemli merhaledir. $\mathrm{Bu}$ yeni siyasetle birlikte imparatorluktan vazgeçilmiş, Batı içi çatışmalarda taraf olmaktan çıkılmış ve artık Batı'nın verdiği yeni biçim kabul edilmiştir. İslamcılığın nakıs bırakıldığı bu yeni siyaset, Batıcılı ve Milliyetçilik sacayakları üzerinden yürütülmüştür. Varlık ve beka sorununu bu yeni siyasetle çözüme kavuşturan devlet için bu yeni siyaseti savunmak ve meşruiyetini sağlamak en önemli ve öncelikli görevdir. Tüm modernleşme sürecinde motor gücü temsil eden devlet, bu yeni siyasette de başroldedir. Fakat imparatorluğun bakiyesi üzerinde bir devlet kurulduğu gerçeği de mevcuttur. Yeni siyasetin savunulması ise bu şartlarda ancak eskinin tasfiyesiyle, onun sövgüsünü yapmakla mümkün olacaktır. Gökalp'ın Kültür-Medeniyet Tezi, 1930'lu yıllarda ortaya atılan Güneş-Dil Teorisi, Anadolu Uygarlıkları gibi tezlerin amacı, Osmanlı'dan

\footnotetext{
4 "Türkiye"nin sahibi ve efendisi, kimdir? Bunun cevabını derhal birlikte verelim: Türkiye'nin sahib-i hakikîsi ve efendisi, hakikî müstahsil [üretici] olan köylüdür. O halde, herkesten daha çok refah, saadet ve servete müstahak ve elyak olan köylüdür. Binaenaleyh, Türkiye Büyük Millet Meclisi Hükûmetinin siyaset-i iktisadiyesi bu gaye-i asliyeyi istihsale [elde etmeye] matuftur [yönelmiştir]" (Atatürk'ün Söylev ve Demeçleri, 2006: 239).

${ }^{5}$ Türkçülüğün Esasları'nda (2008) bu tespiti haklı çıkaracak birçok pasaja rastlamak mümkündür. Örneğin bu kitabın Milli Kültür ve Medeniyet bölümündeki (s. 28-40) pasajlara bakılabilir.

${ }^{6}$ Tek Parti döneminde yaygın bir kullanıma sahip olan ulus ve ulusçuluk, millet ve milliyetçilik kavramları yerine bilinçli bir tercih olarak kullanılmıștır. Millet kavramının uzunca bir zaman din ve mezhep etrafinda bir araya gelen insanları tanımlamış olması, yani milletin hâlâ din ile ikame edilmiș bir toplumu ça ğrıștırıyor olması, tercih edilmemesinde önemli bir faktördür.
} 
vazgeçildiğinin ya da ondan ayrıklığın ifadesinden başka bir şey değildir. Fakat sadece sövgü yeterli değildir; bir de yeni siyaset içerisinde, Yeni Türkiye'de, bir toplumsal taban ihtiyacı vardır. İşte bu köydür, köylüdür. Yeni siyasete uygun bireylerin yetiştirilmesi ihtiyacını işte bu pak/temiz/arı Türk olan, "köylü” sağlayacaktır (Sucu, 2018: 197-8).

Ali Süreyya "Cumhuriyet, kırk bin Türk köyünü birer yoksulluk ocağı halinde buldu" derken, Nusret Kemal, "Osmanlının yıkıntısından enkaz bir köy ile bütün ekonomik varlığı sömürülmüş köylü” kalmıştı demektedir. İsmail Hakkı Tonguç imparatorluk için “...köyler yıkık, memleket 1ssızlaşmış, hayat sönmüştür” (Ertürk, 1997: 5051) ifadesini kullanırken; köycülük davasına sosyolojik bir perspektiften yaklaşan Selahaddin Demirkan (1958: 4) ise "köylüler Türk'tür ve Türk devletin en aşağı tabakasıdır. Osmanlı olanlar Türklerden üstündür. Böyle bir köylü ve Türk anlayışı Meşrutiyet ve hatta Cumhuriyet devrine kadar sürmüştür" diyerek yeni siyasetin bir anlamda yeni hayat önerisini temellendirmeye çabalamaktadırlar. $\mathrm{Bu}$ çerçeveden köy tartışmalarına yeniden bakıldığında; köy/toplum kalkınması dışında köyün/köylünün yeni rejime bir toplumsal zemin sağlama ve böylece yeni rejimin olabilecek meşruiyet sorunlarını giderme çabası olarak ele alındığı aşikârdır.

Osmanlılık ile Yeni Türkiye'yi birbirine zit toplumsal yapılar olarak göstermek, Osmanlı'nın zararının köyde aranması, toplumsal anlamda en çok tahribatın köylerde yapıldığını söylemek ve yine tüm bunlara ek olarak köylüyle Türk'ü eş tutarak Osmanlı'nın köylüyle birlikte Türklüğü geriye ittiği, Türklüğü değil Osmanlılığı öne çıkardığı iddiaları dönemin en çok tartışılan konularındandır. Köylüyü, Türk'ün aslı/safi, köyü de Türklere hakiki yuva olarak ele almanın; Türk medeniyetinin izlerinin ancak köylerde olduğu ve oralarda aranması gerektiğinin; Türk ailesinin sadece köylerde devam ettiğini söylemenin ve yine İslamiyet'in etkisinin köylere az sirayet etmiş olduğunu tartışmanın (Ertürk, 1997: 45-54) gerekçeleri tabii ki vardır ancak şunlar olabilir: $\mathrm{Bu}$ tartışmalardaki en önemli vurgu Türklük meselesidir. İmparatorluğun Osmanlılığına karşı yeni siyaset, Türklüğü ön plana çıkarmıştır. $\mathrm{Bu}$, ulusal bir toplum yapılanması için kaçınılmaz görünmüştür. Osmanlı'nın siyaseten tasfiyesi, onun kültürel olarak da tasfiyesini zorunlu kılmıştır. Dolayısıyla Osmanlı öncesi Türk'le, Türk yaşamıyla/inancıyla bă̆ kurulmak istenmiştir. Burada yeni devletin laik karakteri ve bu konudaki meşruiyet arayışları da etkili olmuştur. Dönemin siyasi kadroları ve aydınları ancak bu şekilde, yani Osmanlı eleştirisi üzerinden Batıc1/Milliyetçi/Laik karakterli bir ulusal devletin varlığını sürdürebileceği tezi üzerinden hareket etmişler ve köyü/köylüyü bu bakış açısından ele alıp değerlendirmişlerdir (Sucu, 2018: 199-200).

Köye yönelik ilginin ideolojik kökeninin bir diğer yüzü ise "köylü toplumu" ya da "tarım toplumu" tanımlamasının siyasi bir yönüdür ki o da şudur: İlk olarak köylülük ya da köycülük Karaömerlioğlu'nun (2009: 285) işaret ettiği gibi 20. yüzyıldaki birçok büyük toplumsal devrimin itici gücü olmuştur. Bu güç aynı zamanda Türkiye gibi siyasal iktidarını yeni tesis etmiş ülkeler için ayrıca sosyalist merkezli ideoloji ve hareketler için de bir panzehirdir. Dolayısıyla köycülük tarım ağırlıklı bir kalkınma ve modernleşmenin yanı sıra aynı zamanda bu kalkınma ve modernleşmenin ideolojik zeminidir. İlkiyle ilişkili ve ikinci olarak ise bir dünya siyaseti yürütücüsü olan Osmanlı İmparatorluğu'nun yıkılışıyla birlikte Batı ile kurulan yeni ilişkide yeni devletin yöneticileri, Osmanlılık siyasetinden vazgeçildiği ölçüde modern medeniyetin temsilcisi Batıyla bir ilişki, daha doğru bir deyişle çatışmasızlık üzerine bir ilişki kurulabileceği üzerinde hemfikirdirler. $\mathrm{Bu}$, yeni devletin bir anlamda varlık ve bekasıyla da çok yakından ilgilidir. Dolayısıyla kurulacak yeni ilişki ancak "üretim ilişkisi" olabilir. Diğer bir deyişle bu üretim ilişkisi endüstriyel üretime ilişkin bir ilişki olamayacağına göre ancak tarımsal üretime dair bir ilişki olabilir.?

Son olarak, Cumhuriyet dönemi köycülüğünü, halkçılığın, köye ve köy sorunlarına yönelen bir türü olarak tanımlayan bir bakış açısından da bahsedilebilir (Tütengil, 1999: 199). Yusuf Akçura'nın "halk” sözcüğünden "köylülükte yaşayan az toprak sahibi yahut büsbütün topraksız rençberler" ve "şehirlerde ufak esnaf ve gündelikçi ameleler, rrgatlar"ın anlaşılması gerektiğine dair vurgusu (Çetin, 1999: 213), halkçılık-köycülük ilişkisini görmemize yardımcı olacaktır.

\section{Toplumsal Dönüşümün Bir Aracı Olarak Köy Enstitüleri $^{8}$}

Köyde istendik bir toplumsal dönüşümün ancak eğitim aracılığıyla mümkün olabileceği ise aşikârdır. Diğer bir deyişle eğitim ve eğitim kurumları olmaksızın köyün/köylünün hem ülke kalkınmasının hem de yeni rejimin ulusçu ideolojisinin temeli olması mümkün görünmemektedir. ${ }^{9} \mathrm{Bu}$ anlamıla Köy Enstitüleri, Kirby'in (2018: 20) ifadesiyle eğitimi Türk toplumunun çağdaş bir toplum durumuna getirilmesinde bir kaldıraç olarak kullanma yolunda, II. Mahmud döneminde başlamış olan deneylerin art arda gelen başarısızlıklarından elde edilen deneyimlerden sonra bulunmuş olan çıkar yoldur.

Köy Enstitüleri, Cumhuriyet rejiminin köy yaklaşımının, romantik veya halkevi/halkodası köycülüğü olarak tanımlanabilecek köye yönelme hareketlerinin yeni bir aşamasıdır. Şöyle ki romantik ya da halkevi/halkodası köycülüğü, Tütengil'in (1999: 208) ifadesiyle “[b]ütün iyi niyetine rağmen, köye dışarıdan bakan, nutukçu ve öğütçü olmaktan kendini kurtaramayan gel-geç köycülük hareketi"dir ve "aydınların köyde yaptıkları piknik gezintileri halini alarak tavsamıştır". Gerçekten köyle ilgilenen yazarların hemen hiçbirinin tipik bir Türk köyünde bir gece bile geçirmeyi göze alacak kişiler olmadıkları; bu aydınların köye gitmeye karar verdikleri zaman da örneğin Ankara Halkevi'nin 1933 yılında düzenlediği köycülük gezisinde olduğu gibi, sanki yabancı turistler ya da Afrika'nın karanlık köşelerinde keşfe çıkan

\footnotetext{
${ }^{7}$ Elinde kılıcıyla at üstündeki savaşçı Türk imgesi, yerini, başında kasketi elinde tarım aletiyle çiftçi Türk imgesine bırakmıştır. Bu değişim, üreticiyi koruyan Sipahi tipolojisinin bizzat üretici/çiftçiye dönüşümü olarak da okunabilir. Böyle bir okuma biçimi ise daha ziyade Prens Sabahaddinci bir Sosyal Bilim' in tarihe uygulanışıdır.

${ }^{8}$ Köy Enstitüleri ile ilgili olarak yazılmış literatür oldukça zengindir. Konuyla ilgili birçok akademik çalışma mevcut olduğu gibi bu ilgi ve çalışmalar günümüzde de devam etmektedir. Bu zengin literatürü takip etmekle birlikte tekrara düşmemek için enstitülerle ilgili birçok ayrıntıya değinilmemiştir.

${ }^{9}$ Sadece eğitimle değil başka mekanizmalar da var elbette, çeşitli tarım ve ulaşım yatırımları gibi. Fakat eğitim olmaksızın sınıfsız/kaynaşmış bir ulus da (dolayısıyla ortak bir kimlik ve kültür de), iş ve amelden gelecek bir teşebbüs de akim kalacaktır.
} 
gezginlermişçesine, köye gittikleri bilinmektedir. 1933'ten önce hemen hemen hiçbir aydın, yalnızca öğretmen okulu çıkışlılar değil, tarihçiler, coğrafyacılar, doktorlar, hatta ilköğretim müfettişleri; köy koşullarını doğrudan incelemeyi, çalışmalarını bir köy içinde yapmayı göze alacak aşamaya gelememiştir (Kirby, 2018: 90-91). Dolayısıyla aydınların kendi olanaksızlıklarının ve görüşlerinin, köy öğretmenlerinin köy ortamında yetişmiş öğrencilerden olması düşüncesinin doğuşuna neden olduğu şüphe götürmez bir gerçektir.

Halkevi deneyi, köycülük konusundaki yetersizliği açıkça ortaya koymuş, aydınların köy sorunları karşısında ne kadar gerçeklikten uzak olduklarını ve köy kalkınmasının başarılmasında ne kadar güvenilmez olduklarını göstermiştir. Kirby (2018: 99), Yakup Kadri'nin Yaban romanının en büyük hizmetinin, "kendi sözde değerleri, önyargıları, savları, beceriksizlikleri ve gerçeklerden habersizlikleri ile Türk aydınlarına Türkiye'nin asıl yabanlarının kendileri olduklarını" göstermesi olarak belirtir. Gerçekten de Yaban'la birlikte Türk aydınları, köy ve köylüyle kendi aralarındaki uçurumun korkunç olduğunu fark etmişlerdir. ${ }^{10}$

Özetle; başlangıçta, köylüyü kentlerdeki halkevlerine ve oralarda verilen konferanslara, kültür çalışmalarına çekmeye girişilmiş, bunun olanaksızlığı görüldükçe de köylere gidilip oralarda toplumsal ve ekonomik konular ile sağlık ve benzeri konularda köylüye öğütler verilmesi yoluna dönülmüştür (Kirby, 2018: 104). Bunun ortaya çıkardığı "yaban" durumuyla birlikte yeni bir model arayışına girişilmiştir. Köy Enstitüleri yine bir kuruma dayanmakla birlikte Halkevi/Halkodası köycülüğünden farklı olarak köylü geçlerin alınıp, köy koşulları içinde uygulamalı eğitimden geçirilip tekrar köylere gönderildiği bir model olarak, Tonguç'un (2019: 96) ifadesiyle "köy meselesi bazılarının zannettikleri gibi mihaniki bir surette (köy kalkınması) değil, manalı ve şuurlu bir şekilde, köyün içten canlandırması" olarak tasarlanmıştır. "Köyü canlandırma meselesi" ise "her şeyden önce bu savaşa katılacak elemanı yetiştirme meselesidir" (2019: 539). Bu model, yalnızca köye öğretmen yetiştiren ve bu sayede ekonomik kalkınmayı hedefleyen bir kurum olarak değil aynı zamanda Türk devrimini halka benimsetmenin bir yolu olarak tasarlanmıştır. Bu açılardan enstitüyü, hem iş ve amelden gelen bir eğitim reformu, hem de ideolojik bir kurum olarak değerlendirmek mümkündür.

Enstitüler, 1935 yılı itibariyle gündem edilmiş, ilk etapta 1936'da Köy Öğretmen Okulları olarak denenmiş ve ardı sıra 1940 ve sonrasinda da Köy Enstitüsü olarak Türkiye'nin tüm sathında toplamda 21 bölgede

\footnotetext{
10 "Onlar gibi olmak, onlar gibi giyinmek, onlar gibi yiyip içmek, onlar gibi oturup kalkmak, onların diliyle konuşmak... Haydi bunların hepsini yapayım. Fakat onlar gibi nasıl düşünebilirim? Nasıl onlar gibi hissedebilirim?" (Karaosmanoğlu, 2020: 68). "Bu vîran ve bu yoksul insan kitlesi için ne yaptın? Yıllarca, yüzyıllarca onun kanını emdikten ve bir posa halinde kanını toprak üstüne akıttıktan sonra, şimdi de gelip ondan tiksinme hakkını kendinde buluyorsun. Anadolu halkının bir ruhu vard1, nüfuz edemedin. Bir kafası vardı, aydınlatamadın. Bir vücudu vardı, besleyemedin. Üstünde yașadığı bir toprak vardı, ișletemedin. O, katı toprakla göğün arasında bir yabanî ot gibi bitti. Şimdi elinde orak, buraya gelmişsin, ne ektin ki ne biçeceksin?" (Karaosmanoğlu, 2020: 111). Yaban romanından alıntılanan bu ifadelerle birlikte Yakup Kadri, aslında tüm köycülük söylemine rağmen politika üreticilerinin köyle olan münasebetlerinin ne kadar problemli olduğunu roman diliyle ifade etmiştir.
}

kurulmuştur. ${ }^{11}$ Enstitüler, köy kalkınmasının merkezi olacak ve iş okulu esasına göre çalışacak, eğitim ile üretimi birleştirecek bir tarzda biçimlenmiştir. Mezunlar hem teknisyen hem öğretmen olacaklardır. 5 yıllık eğitimde 114 hafta kültür dersleri, 58 hafta ziraat, 58 hafta ise teknik dersler verilmektedir. Tasarıya göre 20 yıl içinde okulsuz köy kalmayacak ve Cumhuriyet rejiminin Türkiye'ye getirdiği yenilikler en uzaktaki yerleşim birimlerine kadar ulaştırılacaktır.

$\mathrm{Bu}$ yeni projenin temel aktörü ya da bu yeni projenin yürütücü kadroları bizzat köy çocuklarıdır. Amaç köyü dışarıdan değil, sürecin önemli mimarlarından olan İsmail Hakkı Tonguç'un ifadesiyle “içten canlandırmak"tır. Tonguç’a göre köy meselesi, köyde eğitim problemleri de içinde olmak üzere, köyün 'mihaniki bir surette' kalkınması değil, 'manalı ve şuurlu bir içten canlandırılmasıdır'. Bunun için ise "köy öğretmeninin köyde kalması, köylü gibi çalışması, onlarla 'mukadderat birliği' yapması, köyde ev kurup oturması, aile kurması, sürekli olarak kendini yetiştirmesi” gereklidir (Tonguç, 2019: 96-97). Köyde yapılacak önemli işler vardır, bu işleri yürütecek olan enstitülerden mezun olacak bu köylü çocuklardır. Tonguç bu işleri şöyle sıralar: "a. Köylüyü, ... gıda, giyecek, mesken ve iş vasıtaları gibi ihtiyaçlarını normal biçimde temin edebilecek hale getirmek, b. Cumhuriyet'in yeni değerlerini köylü vatandaşlar arasına da yayarak onlara mâl etmek, c. Hukuki, mali ve ekonomik mahiyetteki bütün işleri, köyün bünyesine uygun bir hale getirmek, verimli k1lmak, d. Köylüleri iyi bir üretici ve memleket sanayi için güvenilebilir birer tüketici haline getirmek ve onları uzun bir maziden sürükleyip getirdikleri olumsuz hayat görüşlerinden, ümmet devrinin aşıladığı adetlerden kurtarmak, yeni hayatın çalışma koşullarına göre hareket edebilecek şekilde, yaşama heveslerini ve ihtiraslarını arttırmak" (Tonguç, 2019: 23).

Tonguç'un köyle ilgili öncelikli işleri izlendiğinde, girişte ifade ettiğimiz Cumhuriyet dönemi köy politikalarının iki temel amacı rahatlıkla açığa çıkarılabilir: Ekonomik kalkınma ve ulusal kültürün yaratımı. Dolayısıyla burada enstitüyü farklı kılan en önemli etken bu değişimin taşıyıcı kadrolarıdır. Hatta Tütengil bununla ilgili olarak "bu yeni tasar1/kurum ve yaklaşım, köye bakışta yenilikler getirse de (köylü aydın kuşağının yetişmesi gibi) her tek yanlı köyü kalkındırma çabası gibi, sadece eğitim yolu ile köyün kalkındırılması (canlandırılması) da, istenilen olumlu sonucu vermemiştir" diyerek, aslında temel farklılığın kadro olduğunu ifade etmiştir (Tütengil, 1999: 208-9).

\footnotetext{
${ }^{11}$ Köye öğretmen yetiştirerek toplum kalkınmasının köyden başlatılmas yönündeki fikirlerin geçmişi, diğer birçok görüş ve düşünceler gibi, II. Meşrutiyet dönemine kadar gitmekle birlikte Enstitü fikrini ortaya çıkaran daha yakın tarihli iki önemli uygulama vardır: İlki 1926'da KayseriZincirlidere ve 1927'de Denizli'de açlan Köy Muallim Mektebi, ikincisi ise önce Eğitmen Yetiştirme Kurslart ve ardından 1937'de İzmir-Kızılçullu ve Eskişehir-Çifteler'de açllan Köy Eğitim Yurdu (Köy Öğretmen Okulu) uygulamalarıdır. Köy Enstitüleri, bu iki kurumsal tecrübe üzerine inşa edilmiştir. Fakat aynı zamanda Köy Enstitüleri'nin bu kurumsal tecrübenin eğitim modeline ve amacına karşıt bir tarzda sürdürüldüğüne dair de ciddi tartışmalar vardır. Bu tartışmaların temelinde ise köye uygun öğretmen yetiştirme görüşünün dayandığ1 iki iş eğitimi yaklaşımının çatışması yer alır. Enstitülerin dayandığı temel felsefenin, Batı'da ortaya çıkan liberal nitelikteki $\dot{I}_{s ̧}$ Okulu akımı mı yoksa Tonguç'un eserlerinde görüldügü üzere Üretim Okulu akımı mı olduğu hâlâ tartışmalıdır. Bu ideolojik farklılığa dair bir tartışma için bakınız: Kafadar, 2012: 369-381.
} 
Enstitülerin ideolojik amacını açığa çıkarma konusunda bize en çok yardım edecek belgeler, enstitülerin kuruluş yönetmeliği ve Meclis konuşmalarıdır. Köy Enstitüleri Yönetmeliği’ne göre 1. "Öğrenciler Cumhuriyetçi ve milli duyguları tam olarak yetişeceklerdir"; Enstitülerden mezun olunca 2. "Köy öğretmenleri, milli ülkü ve maksatları köyde gerçekleştirmeye hizmet edeceklerdir"; ve 3. "Köy öğretmenleri, muhtelif meslek ve zümrelerden teşekkül etmiş olan Türk milletini bir bütün sayacak, onun kalkınmasında, ilerlemesinde kültür adamı sıfatıyla çalışacaklardır” (Kaplan, 2002: 184).

Enstitüler aracılığıyla eğitime, "köylerin gelenekselliğe dayalı yaşam tarzının ortadan kaldırılması ve bu kırsal bölgelerde arzu edilen toplumsal değişim ve dönüşümün gerçekleştirilmesi için hayati bir araç" (Anık, 2006: 287) misyonu biçilmiş, köyleri okul/eğitimle buluşturma ve kısa vadede okuma-yazma oranının yükseltilmesi hedeflenmiştir. $^{12}$ Burada Kirby'in, enstitüleri sadece eğitimsel değil aynı zamanda toplumsal ve kültürel bir hareket olarak görmesine değinilebilir. Kirby (2018: 340), Köy Enstitüleri'ne toplumsal bir hareket özelliğini veren nitelikleri: a. Yeni toplumsal değerlerin gelişmesi, b. Ulusal kültürün yaratılışı, c. Ekonomik yaşamın meslekleşme ve uzmanlaşmaya doğru gelişmesi ve d. Ülke ekonomisinin verimliliğini arttırma sorunu olarak sıralamıştır. Kirby, Meslekleşme, Ekonomik Yaşama Etki ve Doğrudan Doğruya Ekonomik Etki başlıklarında enstitünün ülke ekonomisinin kalkınmasındaki rolüne çeşitli örnekler getirerek vurgu yapsa da, aslında onun şu ifadeleri enstitülerin öncelikle ulusal kültür yaratımına koşulduklarını özetlemektedir:

\begin{abstract}
"Köy enstitüleri zamanında birçok girişim (konservatuar, klasiklerin çevirisi, halkevlerinin kültür ve sanat çalışmaları, çocuk 1slah evleri) kendi alanlarında Türk evriminin gelişmesine gerçekleşmesine doğru atılan adımlardır. Ne var ki, bunların hiçbiri Türk toplumunun şimdiye kadar el değmemiş taraflarına Köy enstitüleri ölçüsünde uzanamamıştır. (...) Köy enstitüleri ise bir kez çalışma yoluna girdikten sonra, çağdaş Türk tarihinde görülmemiş bir işi, Türk toplumunun büyük kitlesine Kemalist devrimin özlemlerine göre etki yapma işini, inanılmaz bir hızla gerçekleştirmeyi ve sonuçlar almayı başardı. $\mathrm{Bu}$ bakımdan eğitmen uygulaması ve enstitülerin bütünü yalnızca eğitimsel değil, aynı zamanda toplumsal ve kültürel bir hareket durumuna gelme özelliği taşır" (Kirby, 2018: 339).
\end{abstract}

Peki Köy Enstitüleri başarılı olmuş mudur? Soruyu her soranın ve cevabı her verenin politik duruş ve dünya görüşüne göre farklılaşmakla birlikte biz burada, enstitülerin gerek kuruluşunu gerekse de kısa süren serüvenini Türk sosyolojisiyle, özelde de Türk sosyolojisi içinde yapılmış köy sosyolojisi çalışmalarıyla ilişkilendirerek ele alacağız.

\footnotetext{
12 Köy Enstitüleri'nde yakın amaç okuma-yazma oranı yükseltmekti. 1928'deki iki yıllık hedefe rağmen 1935 sayımına göre Türkiye'de okumayazma oranı \%15,6 idi (Kaplan, 2002: 182-3).
}

\section{Köye Yönelik Sosyolojik İlgi ${ }^{13}$}

Türkiye'de 1930'lu yılların ikinci yarısından itibaren sosyoloji alanında yapılan köy/kırsal yapı çalışmaları önem kazanmaya başlamıştır. Prens Sabahaddin'in önemli bir ardılı olan ve birçok köy monografisi yapan İstanbul Köy Bürosu Şefi Selahaddin Demirkan'ın “eğer günün birinde Türkiye'nin muhtelif içtimai mıntıkalarında en az bin köyde ilmi tetkikler yapmak mümkün olur ve elde hiç olmazsa bin kadar köy monografyası bulunursa, Türk sosyolojisinin temelleri atılmış olur" (Demirkan, 1946 aktaran Çetin, 1999: 230) tespiti, Türk sosyolojisinin gelişimi için köy/kırsal yapı araştırmalarının önemini göstermektedir. Tabi ki köy çalışmalarının tek amacı Türk sosyolojisine varlık kazandırmak değildir. $\mathrm{Bu}$ mesele önemlidir. Hatta Tütengil (1999: 203), “[b]ugüne kadar köycülük üzerinde hep yabancı bilgiler tedavül etmiştir. Üzerinde yaşadığımız toprak parçasının cevherine, unsurlarına taalluk eden bilgi pek azdır ve bizim anladığımız bir manada 'yerli bilgi' yapılmamıştır" diyerek bu meselenin önemine dikkat çekmiştir. Fakat aynı zamanda köy çalışmaları ya da kırsal yapı araştırmalarının bir diğer amacı, -yukarıdaki başlıklarda ifade edildiği üzere- ülke nüfusunun yaklaşık beşte dördünü bünyesinde barındıran kırın tanınmasıdır. Sosyolojinin 1930'lu yılların ikinci yarısından sonra bu işleve koşulduğu anlaşılmaktadır. Bu sadece sosyolojiye biçilmiş yeni bir misyon değil bizatihi sosyolojinin de Türkiye'deki serüveninin zorunlu bir halkasıdır. Şöyle ki, sosyolojinin Türkiye'ye girişinin en önemli sebebi olarak gösterilen devleti kurtarma ve kalkındırma misyonu, diğer bir ifadeyle devleti ve devletin ihtiyaçlarını önceleyen tavrı, Cumhuriyet'in ilanıyla birlikte misyon kaybına uğrayınca kırsal yapı araştırmaları, sosyolojiye canlılık kazandıran, ona tekrardan itibarını iade eden bir çalışma alanı olarak belirmiştir.

Köye yönelik sosyolojik ilgi aynı zamanda köye yönelik ilmi bir çıkıştır ki, bu kendisinden önceki köy ilgisinden oldukça farklıdır. Niyazi Berkes'in cümleleriyle (1942: 7-8) ifade edecek olursak;

\begin{abstract}
"Nihayet, sosyolojik bakımından köyün tetkikini çok defa karıştırıldığı iki şeyden daha ayırmak lâzımdır. Birincisi, köy sosyolojisi 'köycülük' değildir. Köycülük bir sosyal yardım ve yükseltme cereyanıdır, yani âmeli bir gayesi vardır. Köycü köye rehberlik etmek, bir şey öğretmek için gider. Diğer taraftan, köyü şehirliye ve münevvere tanitmak, sevdirmek ve hatta onu idealleştirmek ister. $\mathrm{Bu}$, inkılabımızın zaruri kıldığı bir ihtiyacın mahsulü olan önemli bir cereyan, sosyal bir hadisedir. İkincisi, köyü her tanıyan, mümkün olduğu kadar çok köy görmüş olan kimsenin sosyolog olması icap etmez. Köyü görme, köyde bulunma ile köyü tetkik etme arasında büyük farklar vardır. (...) Sosyolojik görüş ise, tekerrür eden, muttarit hadiseleri, tavırlanı, münasebetleri ve kıymetleri yakalamağa ve bunlardan tamim [genelleme] yapmağa çalışır".
\end{abstract}

\footnotetext{
${ }^{13}$ Burada sadece Cumhuriyet'in başlangıcından 1950'ye kadar olan zaman diliminde Türk sosyolojisindeki köy ilgisi/çalışmalarına odaklanılmıştır. 1950 sonrasında da köye/kırsal yapıya yönelik sosyolojik ilgi ve araştırmalar hız kesmeden devam edecek ve köy/kırsal yapı, yerli/yabancı araştırmacıların ilgisini çekmeye devam edecektir. Bu çalışmaların bir listesi için bkz. Geray, 1972; Planck, 1977; Kocacık, 1984; Köymen, 1999; Arslan, 2019.
} 
Türkiye'de kırsal yapıyı tanımaya yönelik kapsamlı saha çalışmalarının II. Dünya Savaşı'ndan sonra başladığı yaygın bir görüştür. Gerçekten II. Dünya Savaşı'ndan sonra birçok örneğini izleyeceğimiz köy sosyolojisi çalışmalarında hem nicel bakımdan ciddi bir artış hem de nitel bakımdan bir gelişme görülmektedir. Fakat Türkiye'de, Cumhuriyet döneminde köy araştırmalarının ilk örnekliğini 1936 yılında yaptığı Kurna Köyü monografisi ile Mehmet Ali Şevki Bey'in verdiği de bilinmektedir. ${ }^{14}$ Mehmet Ali Şevki Bey'in esasında Türkiye'nin sosyal monografisini yapma arzusunun Mütareke döneminde başladığını biliyoruz. Şevki, müntesibi olduğu Sosyal Bilim Ekolü'nün sosyolojik yaklaşımı çerçevesinde, Mütareke yıllarında açtığı Meslek-i Íçtima Cemiyeti Ilmiyesi ve yayınladığı Meslek-i İçtima mecmuası vasıtasıyla Türkiye'nin sosyal monografisini çıkarma teşebbüsüne girişmiş, bunun için gereken soru cetvellerini hazırlayıp Anadolu'ya göndermiş, fakat İzmir'in işgali ve ülkenin içinde bulunduğu zor koşullar, bu anket sonuçlarının sınıflamasını imkânsız hale koymuştur. Hilmi Ziya'nın (2001: 443) bildirdiğine göre İstiklal Harbi sonrası 1924'de Ankara'ya giden ve düşüncelerini Maarif Vekâleti çevresine duyuran Şevki, bunun için yapılacak resmi yardımdan faydalanmayı tasarladığı sırada ani bir hastalığa yakalanmış ve bu teşebbüsü yarıda kalmıştır. ${ }^{15}$

Mehmet Ali Şevki Bey’in bu ilk köy monografisi örneği ve bu konuda araştırıcılar için yaptığı anket hazırlığı ve girişimi sonrası Türkiye'de bilimsel niteliği bakımından dikkati çeken ilk monografik araştırmalardan birisi de Sadri Aran tarafindan yapılan Evedik Köyü Monografisi'dir (yayın tarihi 1938). Prens Sabahaddin'in ardıllarından Selahaddin Demirkan'ın 1941'de yaptığı Küçükçekmece ve Celaliye köy monografileri ile bir köyün nasıl incelenmesi gerektiği hususundaki rehber yayınları ilk girişimlerdir. Niyazi Berkes'in on üç köyün toplumsal kuruluşunu, aile yapısını ve ekonomik yaşamını incelediği ve Bazı Ankara Köyleri Üzerinde Bir Araştırma (yayın tarihi 1942) adıyla yayınladığı araştırma ile Behice Boran'ın Manisa'da sekiz ova köyü ile beş dağ köyünü ele aldığı ve dağ ve ova köylerini birbirleriyle karşılaştırarak insan-doğa ilişkilerini, üretim araç ve biçimlerini, işbölümü ve mülkiyet durumunu incelediği Toplumsal Yapı Araştırmaları (yayın tarihi 1945) adlı yapıtı bu alanda çığır açıcı iki önemli köy araştırmasıdır. Bu yıllarda yapılan ve dikkat çeken bir başka köy araştırması ise İbrahim Yasa tarafindan yapılan Hasanoğlan ve Sindel monografileridir. Her iki araştırmada da yazar, sosyal ve ekonomik yapı üzerinden toplumsal değişmeyi ele almıştır. Mümtaz Turhan'ın 1936 gibi erken bir tarihte başladığı ve sonuçlarını 1951'de yayınladığı Kültür Değişmeleri eserinde paylaştığı Erzurum-Kars dolaylarındaki köylerde yaptığı araştırmalar ise hem yaklaşım farklılığı açısından hem de bir yörenin zaman

\footnotetext{
${ }^{14} \mathrm{Bu}$ tarihten önce Türkiye'de yapılmış belki de tek köy araştırması Amerikalı araștırmacı A. Morrison tarafından 1932 yılında, Ankara'nın Alişar köyünde yapılan ve daha sonra Alişar, a Unit of Land Occupance in the Kanaksu Basin of Central Anatolia başlığıla yayınlanan doktora tezidir. Yabancı araştırmacıların bu tarihlerde Türk köyüne ilgisi sadece bununla sinırlı değildir. Paul Stirling'in 1949-50 y1llarında Kayseri/Sakaltutan köyünde yaptığı Türk Köylü Topluluklarının Toplumsal Yapısı başlıklı doktora tezi ile Richard D. Robinson'un 1948-54 yılları arasında Türkiye'nin çeşitli köylerinde yaptığı ve ABD/New York'taki Institute of Current World Affairs tarafindan yayınlanan araştırma raporları da burada hatırlanmaya değerdir.

${ }^{15} 1930$ 'lu yılların ikinci yarısına kadar köy çalışmaları akim kalacak olsa da köy, bu süreçte politik olarak önem kazanmıştır.
}

değişkenine bağlı olarak dönüşümünün izlenmesi bakımından oldukça önemli bir köy sosyolojisi çalışmasıdır. Yine İstanbul Üniversitesi İktisat Fakültesi öğretim üyeleri Gerhard Kessler, Ziyaeddin Fahri Fındıkoğlu ve Orhan Tuna'nın 1944-1950 yılları arasında Zonguldak ve Karabük kömür havzalarında iş şartlarını incelemiş olmaları, her ne kadar iş/endüstri sosyolojisiyle de yakın bağı olsa da Türkiye'de köy sosyolojisinin kurulmasında, özellikle ilk defa geniş bir bölgeyi ele alan bir inceleme olması hasebiyle önemlidir. 1950'li yıllarda ise çok sayıda yeni köy araştırmaları yapılmıştır. Bu araştırmaların öncülüğünü ise İstanbul Üniversitesi Sosyoloji Bölümü ve Coğrafya Enstitüsü yapmıştır. Özellikle Hilmi Ziya Ülken ve Nurettin Şazi Kösemihal isimleri burada hatırlamaya değerdir. Karataş Köyü, Alacahöyük, Ihsaniye, Keçiler, Çatak, Mütevelli, Kayalıoğlu, Yenibedir, Eskitaşlı gibi monografiler yapılan köy tetkiki çalışmalarına örnektir ${ }^{16}$ (Planck, 1977, s. 226228; Sucu, 2018: 200-202).

Türkiye'de 1930 sonrası Mehmet Ali Şevki Bey ile başlayan ülkeyi tanıma hareketi ve köy monografileri yapma girişimlerinden ortaya çıkan çalışmalarda bu çalışmanın odak noktasını da oluşturan temel husus, Mehmet Ali Şevki Bey ile başlayan bu köy ilgisi ve kırsal yapı araştırmalarının, birden çok şekilde/yöntemle/amaçla yapılmış çalışmalar olduğudur. Hilmi Ziya Ülken, 1951 yılında kaleme aldığı (muhtemelen bir yıl önce Fransızca olarak Sosyoloji Dergisi'nde yayınlanan La Sociologie Rurale en Turquie (1950) makalesinin bir özeti olarak sunulan bildiri metni) Türkiye'de Köy Sosyolojisi başlıklı önemli incelemesinde, dağınık ve metotsuz monografiler bir tarafa bırakıldığında, ilmi sahada yapılan köy araştırmalarının üç başlık altında toplanabileceğini belirtmiştir. Bunlardan ilki, maddi değişmelerin manevi hayatı kesin surette belirlediği tezinden hareket eden çalışmalardır. $\mathrm{Bu}$ teze göre Marksist terminolojiyle altyapıda meydana gelen değişmeler üst-yapıyı belirlemektedir. Bugün Ankara Ekolü diye isimlendirdiğimiz Ankara Üniversitesi sosyologlarından Niyazi Berkes ve Behice Boran, bu anlayışla bir takım köy araştırmaları yapmışlardır. Kendilerinden sonra da bu anlayışla yapılmış araştırmalar mevcuttur. İkinci kısımda değerlendirilen köy araştırmaları kültür değişmeleri kuramı tarafindan şekillenmiştir. $\mathrm{Bu}$ araştırmalar ise teknik değişmelerin manevi hayat ve zihniyet üzerinde ciddi bir etkisinin olmadığı ön tezinden hareketle yapılmıştır. Bu tip araştırmaların en önemli ismi ise aynı zamanda kültür değişmeleri tezinin de sahibi olan Mümtaz Turhan'dır. Üçüncü ve son sinıflamada ise Mehmet Ali Şevki Sevündük, Selahaddin Demirkan ve İstanbul Sosyoloji'den bir kısım öğretim üyesi ve öğrencinin 'Sosyal Bilim'in uygulamalı yöntemi ve monografi tekniğiyle yaptığı köy araştırmaları gelmektedir.

Şimdi bu üç farklı yaklaşımla yapılan köy/kırsal yap1 araştırmalarını, Köy Enstitüleri’ni doğuran Tek Parti dönemi köy ilgisiyle, politikalarıyla ilişkilendirilerek ele alacağı.

\footnotetext{
16 İstanbul Üniversitesi bünyesinde yapılan bu monografik çalışmalar, İstanbul Üniversitesi Sosyoloji Dergisi'nde 1950-1956 yıllar1 arasında yayınlanmıştır.
} 


\section{Köye Yönelik Politik ve Sosyolojik İlginin İlişkilendirilmesi}

Yayınlanma tarihlerini dikkate alarak tekrardan sıraladığımızda, birinci tür köy araştırmalarını, kurucu ve etkili isimlerinin Frederic Le Play ve Edmond Demolins olduğu, ülkemizde ise Prens Sabahaddin, Mehmet Ali Şevki Bey ve Selahaddin Demirkan gibi isimler tarafindan savunulan Sosyal Bilim Ekolü'nün sosyolojik anlayış ve yöntemiyle yapılan araştırmalar oluşturmaktadır. Ekol, sosyolojik araştırmaya ve özellikle monografi tekniğine ve istatistiki verilere verdiği önemle bilinmesine ve hatta sosyolojik saha araştırmalarının başlatıcısı bir anlayışı benimsemiş olmasına rağmen, ekolün ülkemizdeki müntesiplerinin oldukça az sayıda sosyolojik araştırma yaptıkları da malumdur. ${ }^{17} \mathrm{Bu}$ ekolün temel yaklaşımı toplumun Sosyal Bilim Ekolü'nün yöntem ve teknikleriyle tahlil edilmesi, ortaya çıkan bilimsel verilerden hareketle de yeni bir toplum tipine (kamucu toplumdan bireyci topluma) dönüşümünün teklifidir. Bu yaklaşımda eğitim, bireyci bir eğitim modeli (Anglosakson eğitim modeli) olarak ele alınır. Bu eğitim modeli bireyi, bireyin bağımsızlığını ve kişisel girişkenliğini önceleyen bir modeldir. Bunun için terbiyenin yönü, görenekten teşebbüse çevrilmelidir. Eğitimin amac1, özel hayatta başarılı olacak aktif ve girişken bireyler yetiştirmektir. Aile ve okul burada aynı anlayıştan beslenen iki eğitim kurumu olarak tasarlanmıştır. Prens Sabahaddin'e (2007: 414-6) göre bu bireyci eğitim hareketini ortaya çıkarmak için yapılması gerekenler; ilk olarak 'Sosyal Bilim'in bireyci eğitime ilişkin incelemelerinden ve İngilizlerin "Public School” ve yeni eğitimsel koşullarından faydalanarak yeni eğitim kurumları açmak; gençlerde bireyci karakterin gelişimi için AngloSaksonların eğitim çevresinden ve özel hayat, çiftlik, aile gibi kurumlarından faydalanmak; son olarak ise bu yönde yetişecek gençleri toprağa güçlüce yerleştirmek ve bağımsızlıklarını kendi çalışmaları ile yaratmayı hazırlayacak gerekli kolaylıkları göstermektir. Bunun için Anglosakson eğitim modeli uygulayacak okullar açılmalıdır. Bu okulun bir örneği Fransa'da Demolins tarafindan kurulan, beden/fikir/ahlak unsurları üzerinden bireyci bir eğitim modeline sahip Ecole de Roches (Kayalar Okulu)'dur. Bu okul örnek alınarak ülkemizde buna benzer eğitim kurumları kurulabileceği gibi ülkemizden bu okula ve diğer Anglosakson okullarına öğrenciler de gönderilebilir. Yine gençlerimizin Anglosakson birey ve ailelerini ve onların yaşamlarını yakından kayıtlamaları için bu ailelerin yanında bir süre kalmaları teşvik edilmelidir. Son olarak ise bu okullarda ya da ailelerin yanında yetişen bireyci/girişimci gençlerin aile kurmaları ve bağımsız yaşamalarını kolaylaştırıcı düzenlemeler yapılmalıdır (Sucu, 2018: 149-150).

Ekolün diğer sürdürücülerinin de eğitimle ilgili, diğer bir deyişle eğitimi toplumsal değişimin bir manivelası olarak kullanmakla ilgili görüşleri bu minvaldedir. Türk sosyolojisini alan çalışmaları ve köy/kırsal alan sosyolojisi ile tanıştırmış olan bu ekolün, burada dikkat çeken iki temel önemi vardır. İlki toplumsal kalkınma ya da toplumsal dönüşüm öncesinde ya da buna aracılık edecek bir eğitim

\footnotetext{
${ }^{17}$ Prens Sabahaddin'in hiçbir monografik çalışması yoktur. Mehmet Ali Şevki Bey ise birçok girişimi olmakla birlikte sadece Kurna Köyü monografisi ile yetinmiştir. Selahaddin Demirkan'ın ise dört monografik incelemesi mevcuttur.
}

sistemi/kurumu inşa etmeden önce bilinmesi gerekenin toplumsal yapının kendisi olduğu önermesidir. $\mathrm{Bu}$ aynı zamanda sosyolojiyi de bilim olarak öne çıkaran bir yaklaşımdır. Toplumsal yapı araştırmalarıyla politika üretimi arasındaki ilişkinin önemine yapılan bu erken vurgu, bu yaklaşımı farklılaştıran bir vurgudur. ${ }^{18}$

İkincisi ise örnek okul uygulamasıdır ki; bu okul, Prens Sabahaddin'in de övgüyle bahsettiği Ecole de Roches (Kayalar Okulu)'dur. Bu okul Demolins'in İngiltere ziyaretinde gezdiği ve hayran olduğu bazı İngiliz özel okullarının Fransız modelidir. Bu okullarda teorik eğitimin yanı sıra aynı zamanda birçok alanda el becerilerine dayalı uygulamalı eğitimler de verilmekte; öğrencilerin, zihinsel gelişimlerinin yanı sıra bedensel ve kişilik gelişimleri de dikkate alınmaktadır. Hem Fransa'nın hem de Fransa dışında bazı ülkelerin eğitim reformuna kaynaklık eden bu okul türünün bir örneğini ülkemizde II. Meşrutiyet'in ilk yıllarında ilk Osmanlı eğitimcilerinden Satı (El-Husri) Bey'in kurduğu Yuva adlı okul oluşturmaktadır. Köy Enstitüleri'ni de bu kapsamda değerlendiren düşünceler vardır. Özellikle enstitülerde teorik eğitimin yanı sıra birçok alanda el becerisine dayalı eğitimlerin veriliyor olması, bu iki okul türünün ortak yanlarının olduğunu göstermektedir. Ülkemizde Kayalar Okulu'na eş değerde açılmış olan okul, Prens Sabahaddin'in kişisel dostluğunu kazanmış ve ayrıca ekolün içinde yer alan bir isim olan Nezahet Nurettin Ege tarafindan 1953 yılında açılan Güneş Koleji'dir. ${ }^{19}$

Fakat bununla birlikte Sosyal Bilim ekolünün eğitim anlayışı ile enstitülerin ilişkilendirmesinde iki zorlukla karşılaşılmaktadır. Bunlardan ilki Le Playci/Demolinsci eğitim anlayışının "elit yetiştirme”ye dair bir amaç gütmesidir. Ekolün genel fikriyatıyla da uyumlu olarak bu anlayış, muhafazakâr bir ideolojiyle bezenmiş fakat endüstri sonrası koşulları da görmezlikten gelmeyen, aristokrat sorumluluğunu yeni üretim ilişskilerinde işverenlere devreden, toplumu yeni elit sinıfların etkin olduğu bir tarzda tasarlamaktadır. Eğitime öncelikle tabi tutulacak zümreler çerçevesinden bakıldığında enstitülerin önceliğinin, orta-üst sınıf varlıklı ailelerin, ya da bölgelerinde egemen olan ailelerin çocukları değil orta-alt sınıf ailelerin çocuklarının olduğu görülmektedir. Sosyal bilim ekolünde yeni elitlerin toprak sahibi ya da işveren olarak sorumlulukları altında bulunan işçilere dönük bir rolmodelliği söz konusudur. Bu rol-modelliğinin sürdürülmesi ise bir taraftan ekonomik ve sosyal sermayeleriyle ilişkili olsa da diğer yandan da ortak anlam dünyalarına -yani muhafazakârlığın ortak değerler dünyasına- kendilerini ait hissetmeleriyle de ilişkilidir. Bu açıdan enstitü çıkışılıların hem aile-soyu itibariyle yani ekonomik ve sosyal sermaye

\footnotetext{
${ }^{18}$ Fakat bu erken vurguyla birlikte Prens Sabahaddin ve ardillarında, toplumun kamucu bir karakterde olduğu ön yargisı kesindir. Yani her ne kadar toplumsal bir değişim için toplumsal yapı analizini öncelemiş olsa da bu ekol, Türk toplumuyla ilgili yapı analizleri öncesi kesin bir yargıya ve teklife sahiptir

${ }^{19}$ Prens Sabahaddin'in önemli ardıllarından olan Nezahet Nurettin Ege ve ailesi tarafindan 1953'te Erenköy Güneş Koleji adıyla açılan bu kolej, Türkiye'nin Kayalar Okulu iddiasıyla açılmıştır. Öyle ki kolejin yeni yeri için 1955 'teki temel atma törenine katılan Tütengil, her iki okulun misyon benzerliğini ifade etmiş, Fındıkoğlu ise Ege ailesini, "şahsi teşebbüsçülüğe, hürriyete ve ekmeğini taştan çıkaran bir zihniyete dayanan bir terbiye telakkisi sahip" olarak tanıttıktan sonra, ailenin, savunusu içinde oldukları eğitim sistemini aile dışında ve şehir ölçüsünde geliştirme imkanı vermek için fikirden harekete geçtiklerini ifade etmiştir (Tütengil, 1955: 160).
} 
sahibi olmayışlarıyla hem de köyün oldukça heretik anlam dünyasına karşı duruşlarıyla farklı modeller olduğu açıktır.

İkinci zorluk ise Prens Sabahaddin ve ardıllarının yaptığı onca memur toplum eleştirisine ve şiddetle önerdiği bireysel girişkenliğe/özel teşebbüse (Sucu, 2018: 130-145) rağmen enstitülerin "eğitmen" yetiştirme amaçlı kurumlar olmasıdır. ${ }^{20}$ Yani bu enstitü çıkışlilar tüm bu donanımla birlikte yine devlet memuru olarak iaşelerini teminde, kendi kişisel girişkenliklerine değil devlete bağımlı olacaklardır. Oysaki Sosyal Bilim ekolü, bireylerin eğitimle desteklendikten sonra kendi işlerini kurmalarını tavsiye eden ve ancak bu şekilde bireyci bir toplumun varlık kazanabileceğini iddia eden bir ekoldür.

İkinci tür köy araştırmaları maddi değișmelerin manevi hayatı kesin surette belirlediği tezinden hareketle yapılan araştırmalardır. Bu yaklaşımla yapılan köy araştırmalarını Ankara Dil ve Tarih-Coğrafya Fakültesi'nde 1939 ve sonrasında göreve başlayan sosyologların araştırmalarında izlemekteyiz. Sosyoloji eğitimlerini Amerika'da tamamlayan ve dolayısıyla Amerikan sosyolojisinin yaklaşım ve yöntemlerini benimseyen bu sosyologların en bilinenleri Behice Sadık Boran ve Niyazi Berkes'tir. ${ }^{21}$ Her iki isim ${ }^{22}$ için de sosyoloji yapmadaki amaç, "çeşitli toplum tiplerinde, farklı zaman ve mekân koşulları altındaki temel ilişkilerin, doğa-insan ilişkilerinin somutta gösterdiği farklılıkları ortaya çıkarmak, sosyal değişme kapsamında kurumların değişme yönünün ve ölçüsünün ne olduğunu tüm boyutlarıyla ortaya koymaktır” (Kaçmazoğlu, 2012: 33). Amerika'daki uygulamalı kent sosyolojinin Türkiye şartlarında köy sosyolojisine dönmüş olması ise gelişmişlik koşullarıyla alakalıdır. Ayrıca zaten köy çalışmaları sadece köy sosyolojisi çalışmaları değildir. Amaç toplumsal yapıyı analiz etme ve toplumsal değişme yönünü ve hızını belirlemedir. Değişimi (teknikle münasebeti) hızlandırarak Batıyla, Batıdaki gelişmiş endüstriyel kentlerle bütünleşmedir. Boran'ın 1940-1941 yıllarında Manisa'da toplamda 13 dağ ve ova köylerini incelediği araştırması (Boran, 1945) ile Berkes'in 1940-1942 yillarında Ankara'daki 13 köy incelemesi (Berkes, 1942), bu yaklaşımın en bilinen köy araştırma örnekleridir. ${ }^{23}$ Her iki araştırma da klasik köy monografisi değildir. Yani yöntem ve teknik açısından Prens Sabahaddinci ekolle çeşitli benzerlikleri olsa da sosyolojik araştırmalarının temel nesnesi açısından farklılaşmaktadırlar. Burada amaç "köyden hareket ederek toplumsal bütüne bir projeksiyon tutmak, elde edilen bulgulardan hareketle toplumsal yapıyı çözümlemektir" (Alver, 2002: 192). Yinelemek gerekirse, buradaki temel unsur toplumsal değişmedir. Her iki sosyolog da toplumsal değişmeyi, Marx'in terminolojisini kullanarak, üretim araçlarının ve kullanılan enerji türünün

\footnotetext{
${ }^{20} 1950$ 'de 18.426 olan toplam köy öğretmeni sayısı içinde enstitü çıkışlı öğretmen sayısı 13.182'dir, bu oran toplam köy öğretmeni sayısının $\% 71.54$ 'üne denk gelmektedir.

${ }^{21} \mathrm{Bu}$ iki ismin yanı sıra Mediha Berkes, İbrahim Yasa ve Mübeccel Belik Kıray da bu ekol içinde değerlendirilmektedir.

22 Niyazi Berkes, 1960 sonrası çalıșmalarında bu ilk yaklaşımından uzaklaşacak, tarihsel bir anlayışa evirilecektir.

${ }^{23} \mathrm{Bu}$ iki önemli araștırmanın yanı sıra yine Ankara Ekolü sosyologlarının çıkarttığı ve 1941-44 yılları arasında 42 sayı yayınlanan Yurt ve Dünya dergisi de, köy sosyolojisi temalı yazıların ağırlıklı olarak yayınlandığı önemli bir neşriyattır. Bu dergideki köy merkezli yazıların bir incelemesi için bakınız: Yalçınkaya, 2013.
}

değişmesi ile birlikte yaşanan evrensel bir toplum hadisesi olarak kavrar. Burada değişmeyi sağlayacak olan ise teknolojik gelişmedir, köyün ve köylünün teknolojiyle buluşmasıdır. Bunun doğal sonucu tarımsal üretimde makineleşme ve ortaya çıkaracağı artı-nüfus olacaktır. $\mathrm{Bu}$ artı-nüfus ise iç-göçle birlikte şehirlere yönelecek ve köye tekniğin girişiyle paralel seyreden şehirlerde oluşmaya başlayan endüstride istihdam edileceklerdir. Demek ki köy kalkınması esasında bir toplumsal kalkınma hareketinin bir cüzüdür ki, köye tekniğin girmesiyle şehirleşme ve sanayileşme eş-zamanlı vuku bulan hadiselerdir.

Köy meselesine bu bütüncül bakıșı (Boran, 1945: 16; Berkes, 1942: 5-6) her iki sosyologda da görmekle birlikte Boran'ın, Köy Davası 'Şehirleşmek' Davasıdır başlıklı makalesinde konunun şu şekilde ifade ediși dikkate değerdir:

"Köy kalkınması memleketin dahilî
meselelerinin başında geliyor. Bu hususta ileri
sürülen fikirlerde iki türlü haleti ruhiyenin hâkim
olduğu görülüyor. Biri, hayırperver, merhametli
kimselerin aldığı tavırdır. Sürdügü basit ve iptidaî
hayattan dolayı köylüye acımak ye onlara yardım
etmek arzusile elbise, ilâç dağıtmak, köye doktor
götürmek vesaire. Diğeri, köy ve köycülüğün
romantikleştirilmesi ve bir köy ütopisi
kurulmasıdır. Köy ütopisinde yapılmak istenen şey
köyü "köy" olarak idame ettirmek, insanları
toprağa bağlı bırakmak, şehirlere muhaceretine
mani olmaktır. "Tekrar tabiata dönmek" nevinden
romantik, köyü idealize eden bir zihniyettir. Bu
noktai nazarların her ikisi de köy meselesini
halletmek için lâzım gelen reel ve rasyonel
zihniyete yabancıdır. Zira "Köy meselesi"ni kendi
başına bir mesele addediyor ve bizatihi halle
kalkıyorlar. Köyün daha geniş cemiyet
bünyesindeki mevkiini nazarı itibara almıyorlar.
Halbuki köy meselesi daha geniş cemiyet bünyesi
zaviyesinden görülmedikçe, meselenin mahiyeti
anlaşılamaz ve anlaşılmayınca hal de edilemez"
(Boran, 1940a: 172).

Görüleceği üzere burada esas olan köy ve şehir ile tarım ve sanayinin eğitim, teknik ve diğer hususlarda aynı seviyede birleşmesidir. Yani köy, ancak üretim araçlarındaki değişimle ve bu değişimin ortaya çıkaracağı yeni ilişki biçimleri ve zümrelerle birlikte dönüşecektir. Fakat bu değişimin yönü, "köyü köyde ve köylü olarak" bırakmak değil bilakis köy-kent arasındaki eğitim ve teknik farkı sıfırlamaya doğrudur. Bu ise enstitülerin kuruluş amaçlarına uygun değildir. Çünkü enstitü projesi, köy ile kent arasındaki gelişmişlik farkını ortadan kaldırmak yerine, köylüyü köyde tutarak, köyle kent arasına kalın bir çizgi çizmiştir. Enstitülerin mimarlarından dönemin Milli Eğitim Bakanı Hasan Ali Yücel'in ifadesiyle Köy Enstitüleri Kanunu'nun dayandığı temel esas 'köylü çocuklarının köyler içinde kalması", şehre akın etmelerinin engellenmesidir. Yücel, kanunun meclis görüşmesinde şu cümleleri sarf etmiştir:

"İçtimaî bir sınıf doğurma meselesi mevzubahs değildir. Partimizin programında da yazıldığ 1 veçhile esasen rejimimiz sınıf ve imtiyaz kabul etmez. Yalnız hayat tarzı bakımından meslekî zümreler, biz ister kabul edelim, ister kabul etmiyelim, mevcuddur, çiftçi vardır, demirci vardır, tüccar vardır, memur vardır. Bunlar bir takım çalışma ve iş zümreleridir. Başka bir siyasî 
ayrılık ifade eden kümeler değildirler. Böyle olduğuna göre zaten köylü ve çiftçilik etmekle meşgul olan vatandaşlarımızın çocuklarını okutmak için onların hayatından başka bir hayatla ülfet etmemesini istediğimiz ve o bakımdan yetiştirdiğimiz insanları yeni bir sınıfin müvellidi addetmeği bendeniz doğru bulmuyorum. Kaldı ki bizim arzumuz, bir arkadaşımızın da burada izah ettiği gibi, köyün içerisinde bilgili, sıhhatli, memleketine bağlı ve müstahsil vatandaş yetiştirmektir. Yoksa köylüyü, bu arzettiğim bilgi ve melekelerle teçhiz edip onları şehre akın eder vaziyete getirmek değildir. Onları müstahsil, kendi tarlasında ve muhitinde kuvvetli yapmak ve istihsal kabiliyetini arttırıp memleketin sosyal seviyesi kadar ekonomik seviyesini de yükseltmektir. Binaenaleyh sınıf teşekkülü hatıra gelemez" (Binark, 2004: 1362-3).

Bu açıklamalardan da görüleceği üzere hem köylüyü köyde tutmak $^{24}$ hem de bir sinıf teşekkülünü engellemek enstitülerin temel hedefi olunca bu kuruluş amaciyla Boran ve Berkes'in köyden kente, tarımdan endüstriye ve doğudan batıya temel değişim aksı, birbiriyle çelişmektedir. Çünkü Ankara ekolüne göre köy meselesinin çözümü "ziraatı ticaret ve sanayideki tempoya, köy hayatını şehir hayatındaki tempoya uydurmak"tan geçmektedir (Boran, 1940a: 174). İç-göç ise kaçınılmaz ve zaruridir: "Köylere modern teknik, rasyonel ve makineleşmiş teknik, girdiği zaman şehirlere muhaceret fazlalaşacak fakat ziraî istihsal inhitat etmiyecektir". (...) "Memleketimiz iktisadiyatının inkişafı programının diğer bir cephesi de sanayileşme olduğundan, bir kısım nüfusun ziraatten ayrılması sanayileşmenin tahakkuku için lüzumludur. $\mathrm{Bu}$ nüfus sanayi ve madencilikte lâzım gelen sâyi temin edecektir" (Boran, 1940b: 177).

Boran ve Berkes'in köye yaklaşımları ile enstitülerin yaklaşımı arasında iki noktada benzerlik görülmektedir, ya da diğer bir deyişle iki noktada Ankara ekolü sosyologları enstitüleri olumlamaktadır. Bunlardan ilki eğitimin dönem itibariyle Türkiye'nin mevcut koşulları düşünüldüğünde maliyetli bir iş olduğu fakat enstitü örneğinin "eğitimde devletçiliği ekonomik kalkınma planıyla ilmiklemekle sanki kendiliğinden finanse etme"nin (Berkes, 2015: 116) bir yolu olduğudur. Enstitü karşıtı çeşitli yazarlarca eğitimin yükünün köylünün ve öğrencilerin sırtına bindirildiği için eleştirilen bu yaklaşım, dönem itibariyle az maliyetle tüm yurt sathında girişilen bir proje olarak burada övülmüştür. İkinci bir ortak nokta ise din ve dinî müeyyidelerin etkisi hususunda görülebilir. Gerek enstitüler gerekse de Ankara ekolü sosyologlarında din ve din çatısı altında varlık kazanmış gelenek ve göreneklerin sekülerleşmesi istenci belirgindir. Enstitüler bunu mezunları aracılığıyla yaparken Ankara ekolünün düşüncesi teknik gelişmenin ve doğal olarak köy-kent ilişkisinin gelişmesiyle birlikte bunun zorunlu olarak vuku bulacağı yönündedir. Boran'ın köy çalışmalarının sonuçlarından biri olan "din ve dinî müeyyide köyde bir otorite kaynağı olmaktan çıkmıştır. Ova köylerinde dinî otoritenin hemen hiç yeri yoktur; dağ köylerinde zayıflamıştır”. (...) “[B]ugün din mühim bir

\footnotetext{
${ }^{24}$ Kemal Tahir de (2016: 170) aynı düşüncededir: "Çünkü ana fikir, bugünkü köyün kendi kendine yeterli kalmasından ayrılamamıștır. Bugünkü köyün kendine yeterliği demek, insan toplumunun sosyal ișbölümü anlayıșının en ilkel üretim çağında yaşamaya çabalaması demektir ki çıkarı yoktur".
}

müessese olarak telakki edilemez; idari-siyasi otoritenin, dışla münasebetleri kontrol edebilmenin ehemmiyeti artmış ve köyler daha da 'açık', şehirleşmiş topluluklar haline geldikçe bu daha da artabilir" (Boran, 1945: 244) tespiti ile enstitü mezunlarının köyleri ve köylüyü "aydınlatma" misyonlarıyla donanmaları benzerdir. Fakat hemen burada Boran ve Berkes'in köylerin aydınlanma ve sekülerleşme sürecinin öncelikle eğitim yoluyla değil de ekonomik gelişme yoluyla olduğu da hatırlanmalıdır. Berkes enstitü öncesi dönemden şu şekilde bahsetmektedir:

"Bütün Türkiye'yi okur-yazar insanların
memleketi yapmak fikri de bir ham hayal olarak
kalmıştır. Anlattığımız şartlar altında kırk bin köye
okul ve öğretmen vermek iddiası eğer safdillik
değilse, salt yalancılıktır. Yazı ve dil devrimleri
gibi, millet mektepleri gibi toplumun çoğunluğunu
okur-yazar hale getirmek isteyen tedbirler
ekonomik kalkınma programının şaşılığından
ötürü, beklenen sonuçlan vermemişlerdir...
Köylerde devlet eli ile "aydınlatma" adına yapılan
şeyler idare amirlerinin yatır yıkmak, üfürükçülük
yasak etmek, çocuktan zorla okula devam ettirmek
gibi köylünün içinde yaşadığı ekonomik şartlar
değişmedikçe faydası olmayan, durup dururken
köylüyü aydınlanmaya düşman eden işlemlerden
öteye geçmedi” (Berkes, 2015: 117-8).

Enstitü aslında tam da bu ekonomik temelden yoksun eğitim politikası için yeni bir soluk olsa da, toplumun ekonomik düzeni değişmediğinden, ya da enstitü hareketine paralel bir değişme yaşanmadığından enstitü aşısı tutmamıştır. $^{25}$

$$
* * *
$$

Üçüncü tür köy araştırmaları toplumsal değişmede manevi hayat ve zihniyeti öne çıkaran, Ülken'in deyişiyle (1951: 25) "teknik değişmelerin manevi hayat ve zihniyet üzerinde ne gibi değişmeler yaptığını” önceleyen araştırmalardır. Bu araştırma tarzının en önemli temsilcisi ise Mümtaz Turhan ve onun Kültür Değişmeleri tezi ve aynı adı taşıyan kitabıdır (Turhan, 1987). Turhan, sosyal psikoloji ve sosyal antropoloji eğitiminin yönlendirmesiyle, diğer iki köy araştırmasından farklı bir tahlil tarzıyla, Erzurum köyleri üzerine yaptığı uzun süreli (1936-48) araştırmalar sonucunda, salt tekniksel bir gelişmenin toplumsal değişme için yetersiz olduğunu, asıl değişmenin zihniyet düzeyinde cereyan eden "serbest kültür değişmeleri" olduğunu

\footnotetext{
25 “Köyü yazarsın. Mektebi de açarsın. Ama sen bana bak, efendi: Köyün dirliğine el atmadıkça, Keltepe'ye mektep değil ya, darülfünun açsan nafile. Sen köyün dirliğine el at oğlum, köyün dirliğine bak..." Şevket Süreyya Aydemir'in Toprak Uyanırsa romanındaki bu ifadeler (1975: 82) ile Kemal Tahir'in Bozkırdaki Cekirdek (2016:164) romanındaki “... koca bir istibdadı deviren inkılapçılar bilmiyorlar ki, köyü yaşatacak okul değildir, okulu yaşatacak köydür. Öyleyse, 'köylü bizden nasıl bir okul istiyor?' diye düşünmeliyiz. Yoksa hükümet zoruyla kurulan okul da mekanik olarak dıştan kurulan her müessese gibi böyle dayanak noktası bulamaz, en geç batar" cümleleri, meselenin aynı minvalde fakat roman diliyle ele alınışına örnektir.

$\mathrm{Bu}$ konuda Berkes'in Hindistan ve Japonya karşılaştırması da ilginçtir: "Hint düşünürü Seyyit Ahmet Han yurduna dönünce 'bireylerin aklını aydınlatma' düşüncesiyle İngiliz modeli Aligarh kolejini kurdu. Ben, altı yıl önce bu kolejde bulunduğum zaman neden kimsenin aklının aydınlatılmadığını anladım: Seyyit Ahmet Han topluma değil, bireye baktığından kolejini Hindistan'ın en koyu zemindar feodalitesinin göbeğine kurmuş; bu yüzden bu aydınlanma merkezi, tersine Müslüman gericiliğin merkezi haline gelmişti. Japonya'da ise tam bunun tersini gördüm: önce toplum ekonomi düzeni değişmeye başladığından bütün aşılar tutmuş" (2015: 176).
} 
belirtmiştir. Diğer bir ifadeyle "esaslı teknik değişmelerin olduğu yerlerde bile bu tekniği doğuran garp ilim zihniyeti ve kıymet âliminin köylere sokulmadığı, yâhut basit/sınırlı miktarda sokulduğu neticesine ulaşmış" (1951: 25) olması, Turhan'1 hem yöntem hem de sonuç itibariyle farklılaştırmıştır.

Köy kalkınması meselesine dair görüşlerine ve köy sosyolojisi araştırmasını incelemeden önce Turhan'ın iki husustaki fikrinin bilinmesi önemlidir. İlki onun sosyolojiyi de içine alacak şekilde toplumsal yapının ilmi olarak tanınmasına verdiği ehemmiyettir. Kendisinin Thornburgh'un düşüncesine iştirak ederek, Türkiye sınırları içinde iktisadi bakımdan yüzlerce küçük Türkiye'nin mevcut olduğu ve bu "Türkiyeciklerin de içinde, yine iktisadi ve içtimai bakımdan, birbirinden farklı yüzlerce köy bulunduğu" fikri ile; "Türkiye'de köyün 'kültür'ü ile başlı başına müstakil bir varlık oluşu" fikridir. O, "bu itibarla köy bünyesini değiştirmek maksadıyla, onun üzerinde yapılacak içtimai operasyonlarda bu noktanın bilhassa göz önünde tutulması"nı şart koşar. Yine Turhan'ın "Türkiye'nin kalkınması ve sanayileşmesi neticesinde, kaçınılması imkânsız bazı içtimai sarsıntılar" olacağı öngörüsü ve bunlara karşı hazırlıklı olması önerisi (Turhan, 2015: 116); tam da sosyolojiye açılan kapıdır ki, Turhan birçok vesileyle şunu ifade etmiştir: “...Onun için diğer sahalarda olduğu gibi köy davasının da ancak birinci sınıf, muhtelif ilim kollarına mensup, mütehassıslardan müteşekkil heyetlerin etraflı tetkikleri neticesinde teklif edecekleri çarelerle halledilebileceğine kaniyiz" (Turhan, 2015: 115).

İkinci husus ise şudur; Turhan'ın köy kalkınması ile ilgili görüşlerinin anlaşılması, ancak onun Türk modernleşmesine dönük eleştirileri ve bu konudaki önerileriyle bir anlama kavuşabilir. Özetle ifade etmek gerekirse Turhan, hem batının özünün yanlış anlaşıldığı hem de bu "kültür değişmeleri" sürecinin serbest değil "empoze/güdümlü/zorunlu" bir tarzda icra edildiği eleştirisini getirir. Turhan’a göre "garp medeniyetinin esas unsurları, ilim, ilmin ameli hayata tatbikinden ibaret olan teknik, insan haklarını teminat altına alan hukuk ve hürriyettir. Hakiki garplılık ise bunların prensiplerine bağlılıktır" (Turhan, 2015: 46). Batının özünü bu şekilde tanımlayarak Turhan, aslında Türk devrimi sonrası batılaşmanın aksayan yönlerini gidermek için bilimin rehberliğine sığınmaktadır. Aynı zamanda Turhan bu yolla, Akpolat'ın tespit ettiği gibi (2009: 364), bilimi teknikle ilişkilendirerek ve tekniği de maddi kültür veya uygarlık sınırlarında değerlendirerek, bir toplumun manevi kültür yanını ve eğilimlerini korumanın ilmi yolunu da göstermiştir. Bunun yolu ise "serbest kültür değişmeleri"dir. Ancak bu şekilde, yani toplumun sert kültür unsurlarını dikkate alan, sembolleşmiş kıymet hükümlerini hedeflemeyen, daha muhafazakâr bir modernleşmeyle sürdürülebilen bir modernleşme, kalıcı olabilir.

Turhan burada, bir taraftan modernleştirici bürokrat yerine "birinci sınıf ilim adamları"nı yani teknokratları yeni aktörler olarak öne çıkarmakta, diğer taraftan da batının özünün kavranışını ve batılılaşma sürecini eleştirerek, aslında Gökalpçı sentezi ve modernleşme tarzını yeniden gündeme almaktadır. Bunu yaparken de temel verilerini köyden temin etmektedir.
Türk modernleşmesini bir kültür değişimi olarak ele alan Turhan, bu kültürel değişimi izlemek için Erzurum ile Kars arasında bulunan Erzurum'un beş köyünü seçmiştir. Bu köylerin yaşadıkları kültürel değişimi, 1936-1948 yılları arasinda ve takriben toplamda bir seneyi bulan gözlemleriyle incelemiştir (Turhan, 1987: 65). Burada köyün hem maddi hem de manevi kültür unsurlarının değişimini ele alan Turhan, kültürel değişimde önceden topluluğun zihnen değişime alıştırılmasının önemi üzerinde durmaktadır. Böyle bir zihinsel alışkanlık, değişimi kolaylaştırmaktadır. Turhan'ın, farklı bir açıdan, pozitivist benzerleri gibi, topluluğa aniden yapılan müdahalenin sakıncaları üzerinde durduğu (Akpolat, 2009: 364) bu yaklaşımda, zorunlu değil serbest kültür değişmelerini öncelediği açıktır. Çünkü ona göre bir kültürün içinde, onun özüne ait, onun işlemesi açısından hayati önemi bulunan "sert" unsurlar vardır ve bunların değişimde öncelenmesi veya dikkate alınmaması daima tepki ve direnç yaratır (Demirel, 2007: 230). Bunun için değişime, kültürün din/gelenek gibi sert unsurları yerine maddi kültürel bileşenlerden oluşan yumuşak unsurlarından başlamak elzemdir.

Turhan'ın köyü ve köydeki serbest kültür değişimlerini öncelemesinin bir nedeni vardır, çünkü böylesi bir değişmede toplum anomik bir hal almaz, çünkü köylü seçmecidir, kültürel unsurları alırken işe yararlılığına, kendi ifadesiyle "fayda temini"ne bakar. Aynı zamanda da köylü bu kültürel değişim sürecinin kendi anlam dünyasıyla çelişmemesini önemser (Turhan, 1987: 78-88). Bu tespitlerle Turhan bir taraftan köylülerin, her hangi bir teknik yeniliği, işlerine yarıyor ve ona ait teknik bilgileri varsa almakta tereddüt etmediklerini göstermiştir. Ki bu ispatla Turhan, elit-merkezcil aydının Türk köylüsü ile ilgili olumsuz tavrına mukavemet etmekte ve batılılaşma sürecinde alt-yapı ve teknik bilgi ihtiyacının önemini vurgulamaktadır. Diğer taraftan da köy topluluğunun dışarıdan, zorla, kanun zoru ile değişime zorlanmasının yanlışlığını ve dolayısıyla kültür değişimlerinde, topluluğun zihniyetinin değişiminin belirleyici olduğunu göstermektedir (Akpolat, 2009: 369-71).

Tüm bu önemli tespitleriyle birlikte Turhan'ın köy kalkınmasıyla ilgili somut önerileri de vardır. Ayrıntısına burada girmeyeceğimiz Kültür, Teknik ve Sanayi Merkezleri ile İlahiyat Liseleri (2015: 115-128), Turhan'in etraflı bir köy kalkınması için önerdiği kurumlardır. Bu iki eğitim kurumunun Köy Enstitüleri'nden farkı ise bizce iki noktadadır: İlki eğitmen-aktör farkıdır. Bu merkezlerde görev alacak personel Turhan'ın bize Tuba Ăgacl Nazariyesi'ni hatırlatırcasına birinci sinıf ilim ve teknik adamaları ile yardımcılarıdır. Zira Turhan (2015: 83) “... iptidai bir kavmi medenileştirmek gayesiyle, sadece okuma yazma öğretirseniz, okuma yazma bilen iptidai bir kavim elde etmiş olursunuz. Bu itibarla milletler arasında kültür ve medeniyet farklarını doğuran, onların halk tabakaları değil, münevver zümreleridir" diyerek, her firsatta ilk tahsili değil yetişmiş bilim adamalarını öne çıkarmaktadır. Oysaki enstitülerin öncelikli hedefi hem bir okuma-yazma yaygınlığı kazandırmak hem de bir anlamda köyü/köylüyü içinde bulunduğu koşullarla ve kendi çocuklarıyla bir düzeye getirmektir:

"Enstitülerin köyü ve bunun neticesi olmak üzere Türkiye'yi kalkındıracak tipte öğretmen yetiştirdiği 
iddiası ise gülünç olmaktan ziyade acınılacak bir iddiadır: Köylü sadece kırılan sabanını tamir edemediği, penceresinin camını takamadığı, kapısını bizzat yapamadığı veya okur yazar olmadığı, bâtıl itikatlara saplandığı, gelenekçi olduğu için kalkınamıyor olsaydı ve bu Enstitü mezunları da bunları temin etseydi, iddia bu kadar saçma olmazdı. Hakikatte köylü bâtıl itikatlara inandığı veya gelenekçi olduğu için değil, toprağının vasıflarını, hangi gübreyi ve tohumu kullanması lâzım geldiğini, iklim şartlarını bilemediği ve lüzumlu âletlere, vasıtalara sahip olamadığı için kalkınamamaktadır. Bu bilgileri de bir ilk mektep tahsili veremeyeceği için okur yazar olmasının kalkınma bakımından bir ehemmiyeti yoktur. (...) Çünkü bu dâva onların kudret ve bilgileri dışındadır. Bir insan bilmediği, bizzat yapamadığı şeyleri başkalarına nasıl öğretebilir? Köyü kalkındıracak bilgi ilmî bir ihtisas bilgisidir... Bu bilgileri değil köy enstitüsü, alelade bir lisansla üniversite dahi veremez" (Turhan, 1959: 24).

Diğer farklılık ise Turhan'ın İlahiyat Liseleri önerisinde olduğu gibi maddi ve manevi kültür unsurlarını bir aktörde birleştirme ve bu şekilde köylerdeki imam-öğretmen ikiliğine son verme önerisidir. Zira yine bu durum enstitülerin köylerde yaşadığı en belirgin problemdir ki köylü, anlam dünyasına yönelik her müdahale girişiminde, kendisi için faydalı olacak maddi unsurları da aynı yerden geldiği için reddetmektedir:

\begin{abstract}
"Bâtıl itikatlarına ve gelenekçi olmasına gelince, bunlar da kalkınma itibariyle pek mühim değildir. Çünkü bunlar kalkınamamanın sebepleri değil, neticesidir... Bundan başka köyün asırlar boyunca hususî şartlara göre gelişen kendine has iyi kötü bir kültürü olduğu kabul edilmelidir. Her kültürde olduğu gibi dünyanın en halis, en özlü ve en mukavemetli iki unsurunu, Mehmetçik ile anasını yetiştiren bu kültürde de peşin hükümler, bâtıl itikatlar, zararlı unsurlar bulunabilir. Fakat yalnız bunları görüp hakiki kıymetlerini, onun özünü görememek büyük bir gaflet olur. Onun için köy cemaatını, kafası sapık fikirler, peşin hükümler ve başka neviden bâtıl itikatlarla doldurulmuş asrî mollaların eline bırakmak kadar tehlikeli bir şey olamaz" (Turhan, 1959: 24). ${ }^{26}$
\end{abstract}

Fakat bununla birlikte Turhan'in merkez ve okul önerisiyle enstitülerin buluştuğu noktalar da vardır ki o da şudur: İlk olarak köy enstitülerini eleştiren Turhan'ın, merkezcil-elitsol aydınına eleştirel baksa da kendisinin de merkezcil-elitsağ aydın örneği olarak Türk köylüsünü iptidai oluşu bağlamında ele alması, bir şekilde medenileştirilmesi gerektiğini düşünmesidir. Köy enstitüleri gibi köylüyü köyde tutarak medenileştirme projesinin bu sağ versiyonunda sosyal bilimciler bir nevi misyonerlik vazifesi ifa edecekler, iptidai Türk köylüsünü medenileştireceklerdir. Ancak Turhan bu konuda uyarıcıdır, bu medenileştirme projesini sol versiyonundan ayıran bir özelliği gündeme getirir; bu özellik ise kalkınma projesinin halk tarafından benimsenip iştiraklerinin sağlanması için

\footnotetext{
${ }^{26}$ Turhan, Erzurum köyleri araştırmasında da köy okullarında eğitmenlik yapan enstitü çıkışlı öğretmenlere dair benzer sonuçlarla karşılaşmıştır: "İşleri güçleri bir araya gelip içmek mütemadiyen şarkı söyleyip oynamaktır. Âdetlerimize, ahlâk kaidelerine riayet etmiyor, bizleri hakir görüyorlar. Bunlar geleli köylerde hürmet diye bir şey kalmadı..." (Turhan, 1987: 106).
}

köylünün örf ve adetlerine saygı gösterilmesidir (Akpolat, 2009: 376-77). İkincisi ise Demirel'in (2007: 231-233) tespit ettiği üzere Turhan'ın, aynı karşıt oldukları gibi bilimsel faaliyetin, içinde evirildiği sosyal/siyasal çevreden bağımsız bir biçimde transfer edilebileceği; bilimin her türlü kültüre, her türlü toplumsal ilişkiler sistemine kolaylıkla sokulabileceği düşüncesi ve son olarak bilimle ekonomik kalkınma arasında kurduğu doğrudan ilişkide farklı olgusal süreçleri dikkate almamış olmasıdır. Yani Turhan'ın pozitivist bilim anlayışı, "sosyal mühendislikçi eğilimler, iktisadi süreçleri anlama konusundaki sınırlılıklar ve karmaşık devlet-toplum ilişkilerini mekanik bir biçimde algılama"sı noktalarında, Kemalist modernleşmenin yaklaşımıyla benzeşmektedir.

\section{Sonuç: Siyaset Sosyolojinin Uygulayıcısı Olabilir mi?}

$\mathrm{Bu}$ yazı bir sorunun peşinde iz sürmüştür. Soru şudur: Köye yönelik politik ilgi ve bunun temel kaldıracı olarak tasarlanmış Köy Enstitüleri ile aynı dönemde başladığını bildiğimiz köy sosyolojisi çalışmaları arasında bir ilişki kurabilir miyiz? Böyle bir ilişkinin varlığı, siyasetle sosyoloji arasındaki bağın Türkiye'deki biçimini anlamaya da yardımcı olacaktır. Çünkü eğer köy sosyolojisi çalışmaları politik uygulayıcılar için bir kaynak temin ettiyse bu hem sosyolojinin imkânını hem de politik uygulamaların akılcılığını göstermektedir. Yok eğer sosyoloji, politikanın karar ve uygulaması sonrası bunu ya meşrulaştıran ya da yanlışlayan bir pozisyondaysa, bu Türkiye'de siyaset-sosyoloji ilişkisinin özel durumunu ve sosyolojinin ülkeye gelişinden beridir devam eden bir devlet bilimi olma misyonunu gösterecektir.

Cumhuriyet sonrası köy ilgisi, hem ülkenin zenginlik kaynağı hem de rejimin meşruiyet sorunlarını gidermek açısından ön plana çıkarılmıştır. Enstitüler de bu minvaldeki eğitim deneyimlerinden biri ve belki de en başarılısıdır. Toplumsal değişimin bir aracı kurumu olarak enstitüler, köyün sadece kalkınması ve köylünün okumayazma oranlarının artırılması amacıyla değil, bununla birlikte yeni ulusal kimlik ve kültürün merkezden çevreye taşınmasının da temel aracı olarak tasarlanmıştır. Hem üstyapısal/düşünsel hem de altyapısal/ekonomik bir dönüşümün ajanı olsa da enstitüler, dönemin hâkim modernleşme tarzına uygun bir biçimde, pasif olarak tanımlanacak bir modernleşme tarzını benimsemiş, yani bürokrat/aydın öznelerin halkı zihinsel/kültürel olarak aydınlatma misyonu, tekniksel ve dolayısıyla sanayileşme ve kentleşme süreci sürekli olarak ötelenmiş bir modernleşmenin önüne geçmiştir. Bu anlamda enstitülerin kuruldukları bölgelerin ekonomik canlanmasına katk1 sağladıkları görülse de bu durum bir toplum kalkınması olarak görülemez. Burada belki de tek fark, Tonguç'la birlikle enstitülerin yeni bir sınıf teşekkülüne meyletmiş olmalarına dair izlerdir. Yani modernleştirici elitlerin yerini alacak bir köylü/halk sinıfiyla birlikte mevcut modernleşmeyi sürdürmektir. Buradaki tek radikal öğe ise modernleşme tarzında değil, yürütücü kadrodaki değişimdir.

Enstitülerin kuruluş fikri, kendisinden önceki köy eğitmeni deneyimleri ile birlikte düşünüldüğünde hemen hemen aynı yıllarda başlayan köy sosyolojisi çalışmalarıyla aynı zaman 
dilimine denk gelmektedir. Her iki süreci kıyasladığımızda karşımıza çıkan tablo şudur:

- Köy sosyolojisinde birden çok farklı yaklaşım ve yöntemle çeşitli köy araştırmaları yapılmış olmasına rağmen hepsinin paylaştığı ortak fikir, toplumsal yapıyı tanımanın ehemmiyetidir. Ancak bundan sonra gelecek bir politika üretimi gerçekçi ve kalıcı olabilir.

- Prens Sabahaddinci ekolü ister liberal ister muhafazakâr olarak ele alalım her iki durumda da enstitü fikriyle çatışır. Zira sınıfsız/kaynaşmış bir uluslaştırma sürecinde liberal bireyler yetiştirecek okul modeli, mevcut ve hâkim tarza aykırı olduğu gibi; bu ekolün önerdiği eğitim modelinde öncelik topluma yön verecek elitleri yetiştirme olduğu için her iki model, hedefledikleri toplumsal kesim anlamında ayrışmaktadır.

- Ankara Ekolü, toplumsal değişmeyi evrensel bazda ele alan, kırın çözülüşüyle kentleşme ve sanayileşme süreçlerinin eşgüdümlülüğüne önem veren bir bakış açısına sahiptir. Buradaki temel belirleyici husus ise tekniksel gelişmedir, köyün teknikle buluşmasıdır. Enstitülerin köylünün teknik seviyesiyle aynı düzeyde kalmış olması ve aynı zamanda köy-kent arasında bir bariyer olarak yer alması, kırdan kente göçü hoş görmemesi gibi hususlarda bu ekolle enstitüleri çatışır kılmıştır.

- Mümtaz Turhan ise tekniğin toplumsal değişim için önemini vurgulamakla birlikte köyde bir toplumsal değișimin öncelikle zihniyet unsurlarını dikkate almayı bulgulayan araştırmasıyla, kültürün manevi kısmıyla çatışan her türlü değişim unsurunun bir taban tutmayacağını belirtmiştir. $\mathrm{Bu}$ ise modernleşme sürecinde alıcı kültürü de aktif kılan sentezci anlayışın devamı olarak enstitü fikriyle çatışmıştır.

\section{Kaynakça}

Akpolat, Y. (2009). Mümtaz Turhan'da Köy ve Kalkınma: Mevcut Durum ve Öneriler. İçinde: Aramızdan Ayrılışının 40. Yılında Prof. Dr. Mümtaz Turhan Sempozyumu Bildiri Kitabl (s. 362-379). Ankara: Gazi Üniversitesi Rektörlüğü.

Alver, K. (2002). Türk Sosyolojisinde 'Kırılma' ya da Yeni Yönelim: 1940'lı Yıllar Örneği. AKÜ Sosyal Bilimler Dergisi, 4(2), 184-194.

Anık, M. (2006). Bir Modernleş(tir)me Projesi Olarak Köy Enstitüleri. Divan Ilmî Araştırmalar, (20) 1, 279309.

Arslan, H. (2019). Türkiye'de Kır Sosyolojisi Araştırmaları. Ankara: Siyasal Kitabevi.

Atatürk'ün Söylev ve Demeçleri I-III (2006). Atatürk Araştırma Merkezi: Divan Yayıncılık.

Aydemir, Ş. S. (1975). Toprak Uyanırsa. İstanbul: Remzi Kitabevi.

Berkes, N. (1942). Bazı Ankara Köyleri Üzerinde Bir Araştırma. Ankara: Uzluk Basımevi.

Berkes, N. (2015). Türk Düşününde Batı Sorunu. İstanbul: Yapı Kredi Yayınları.
Binark, İ. (2004). Türk Parlamento Tarihi (TBMM - VI. Dönem) II. Cilt. Ankara: TBMM Vakfı Yayınları.

Boran, B. (1940a). Köy Davası 'Şehirleşmek' Davasıdır I. Siyasi İlimler Mecmuası, 111, 172-174.

Boran, B. (1940b). Köy Davası 'Şehirleşmek’ Davasıdır II. Siyasi Illimler Mecmuast, 113, 175-180.

Boran, B. (1945). Toplumsal Yapı Araştırmaları (İki Köy Çeşidinin Mukayeseli Tetkiki). Ankara: Türk Tarih Kurumu Basımevi.

Çetin, T. (1999). Cumhuriyet Döneminde Köycülük Politikaları: Köye Doğru Hareketi. İçinde: O. Baydar (Ed.), 75 Yilda Köylerden Şehirlere (s. 213230). İstanbul: Tarih Vakfi Yayınları.

Demirel, T. (2007). Mümtaz Turhan. İçinde: T. Bora \& M. Gültekingil (Ed.), Modern Türkiye'de Siyasi Düşünce Cilt 3: Modernleşme ve Batıcılık (s. 228233). İstanbul: İletişim Yayınları.

Demirkan, S. (1946). Köyün Sosyal Tetkikinde Monografya Usulü. İstanbul.

Demirkan, S. (1958). Tanzimat'tan Günümüze Kadar Köycülüğümüz. İş ve Düşünce, (24)204-205, 4.

Ertürk, R. (1997). Türk Sosyolojisinde ve Cumhuriyet Döneminde Köy Tartışmalart. İstanbul: İstanbul Üniversitesi Edebiyat Fakültesi Yayınları.

Geray, C. (1972). Toplum Kalkınması ve Köy Araştırmaları. Ankara Üniversitesi Ĕgitim Bilimleri Fakültesi Dergisi, 5(1), 3-49.

Gökalp, Z. (2008). Türkçülüğün Esasları. İstanbul: Kitapzaman1.

Kafadar, O. (2012). Cumhuriyet Dönemi Eğitim Tartışmaları. İçinde: U. Kocabaşoğlu (Ed.), Modern Türkiye'de Siyasi Düşünce Cilt 3: Modernleşme ve Batıcılık (s. 351-381). İstanbul: İletişim Yayınları.

Kaplan, İ. (2002). Türkiye'de Milli Eğitim Iddeolojisi. İstanbul: İletişim.

Karaosmanoğlu, Y. K. (2020). Yaban. İstanbul: İletişim.

Karaömerlioğlu, M. A. (2009). Köy Enstitüleri. İçinde: A. İnsel (Ed.), Modern Türkiye'de Siyasi Düşünce Cilt 2: Kemalizm (s. 268-293). İstanbul: İletişim.

Karaömerlioğlu, M. A. (2009). Türkiye'de Köycülük. İçinde: A. İnsel (Ed.), Modern Türkiye'de Siyasi Düşünce Cilt 2: Kemalizm (s. 284-297). İstanbul: İletişim.

Kazgan, G. (1983). Tarım. İçinde: Cumhuriyet Dönemi Türkiye Ansiklopedisi (Cilt 9, s. 2412-2429). İstanbul: İletişim.

Kirby, F. (2018). Türkiye'de Köy Enstitüleri. İstanbul: Tarihçi Kitabevi.

Kocacık, F. (1984). Köy Araştırmaları. İçinde: Prof. Dr. Aziz Köklü'nün Anısina Armağan (s. 265-276). Ankara: Ankara Üniversitesi Siyasal Bilgiler Fakültesi.

Köymen, O. (1999). Köylü Sorunu Araştırma ve Tartışmaları. İçinde: O. Baydar (Ed.), 75 Yılda 
Köylerden Şehirlere (s. 133-140). İstanbul: Tarih Vakfi.

Mardin Ş. (2008). Jön Türklerin Siyasi Fikirleri 1985-1908. İstanbul: İletişim.

Planck, U. (1977). Türkiye'de Köy Sosyolojisi (Çev. M. Reşit Küçükboyacı). Işsletme Dergisi, 2(4), 223-240.

Prens Sabahaddin (2007). Gönüllü Sürgünden Zorunlu Sürgüne Bütün Eserleri (Yayına Hazırlayan: Mehmet Ö. Alkan). İstanbul: Yap1 Kredi.

Sucu, İ. (2018). Prens Sabahaddin -Türk Sosyoloji Tarihinde Sosyal Bilim Ekolü-. İstanbul: Açılım.

Tahir, K. (2016). Bozkrrdaki Çekirdek. İstanbul: İthaki.

Tekeli, İ. \& Gülöksüz, Y. (1983). Kentleşme, Kentlileşme ve Türkiye Deneyimi. İçinde: Cumhuriyet Dönemi Türkiye Ansiklopedisi (Cilt 5, s. 1124-1238). İstanbul: İletişim.

Tonguç, İ. H. (2019). Canlandırllacak Köy. İstanbul: İş Bankası Kültür.

Turhan, M. (1959). Köy Enstitüleri Masalı. Türk Yurdu, 278, 23-24.

Turhan, M. (1987). Kültü̈r Değişmeleri. İstanbul: MÜ İlahiyat Fakültesi Vakfi.
Turhan, M. (2015). Garplılaşmanın Neresindeyiz. Ankara: Altınordu.

Tütengil, C. O. (1955). Yaşayan Prens Sabahattin Bey Çığırı ve Bir Temel Atma Merasimi. İş Mecmuası, $171,160$.

Tütengil, C. O. (1999). Köycülük Üzerine. İçinde: O. Baydar (Ed.), 75 Yllda Köylerden Şehirlere (s. 199212). İstanbul: Tarih Vakfi.

Ülken, H. Z. (1950). La Sociologie Rurale en Turquie. Sosyoloji Dergisi, 6, 104-116.

Ülken, H. Z. (1951). Türkiye'de Köy Sosyolojisi. İçinde: Sosyoloji Dünyast (s. 22-27). İstanbul: Türk Sosyoloji Cemiyeti Yayın Organı.

Ülken, H. Z. (2001). Türkiye'de Çağdaş Düşünce Tarihi. İstanbul: Ülken.

Yalçınkaya, Z. (2013). 1941-1944 Yılları Arası Yayınlanan "Yurt ve Dünya Dergisi”ndeki Köy ve Köylü Sorunları Üzerine Bir Analiz. Atatürk Üniversitesi Sosyal Bilimler Enstitüsü Dergisi, 17(2), 161-174.

Yıldırım, K. (2019). Cumhuriyet Döneminde Türkiye'de Çalışma Hayatının Gelişimi. İçinde: L. Sunar (Ed.), Türkiye'de Toplumsal Yapr ve Değişim (s. 221-245). Ankara: Nobel. 